\title{
الأحوال السياسية والاقتصادية لمدينة عبادان خلال العصر العباسي
}

أ.م.د. خالدة حمود سلمان الجبوري

الجامعة المستنصرية / كلية التربية

قسم التاريخ

$$
\text { أ.م.د. رغيد كَمر مجيد الخالدي }
$$

الجامعة المستنصرية / كلية التربية

\section{قسم التاريخ}

Email: ragheed gummar@yahoo.com

(مُلَخََّصُ البَحثث)

تعـد مدينـة عبـادان مـن بـين المـدن المهمـة في الدولـة العربيـة الإسلاميــة ، تقـع

على سـاحل البحـر حيـث مصــب نهـري دجلـة والفـرات ، وهـي مينـاء مهــ خــلال العصـر العباسـي، شــــت العديـــ مـن الاحـداث السياسـية والمعـارك الحربيـة. ويعـد النشـاط الاقتصـادي مـن بـين اهـم الجوانـب الحضـارية لكـل مدينـة ، فهـو يبـين نشـاط الانسان في هذا الجانب في مجال الزراعة ، والصناعة ، والتجارة. الكلمة المفتاحية: عبادان ، مدن ، الأحوال السياسية والاقتصادية

(المقدمة:

ان الكتابـة في تـاريخ المـدن يعـد مـن الأمسور المههـــة، فهـي تسـلط الأضــواء على الـى اهـم الأحسوال التي مـرت بهـا مـدننا الإسـلامية عبر التـاريخ، لـللك جـاء هذا البحث عـن مدينــة عبـادان التـي تعـد مـن المـدن المهمــة خـلال العصـر العباسـي ، وتقـع على

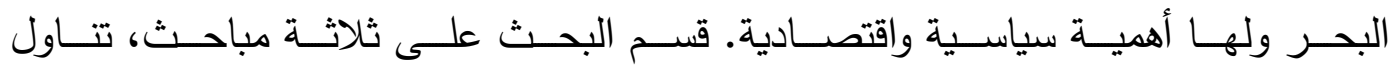
المبحـث الأول لمحــة لاســم مدينـــة عبــادان وجغرافيتهــا ، والمبحــث الثـاني خصـص لدراســــة الأحسوال السياسـية لمدينـة عبـادان ، امـا المبحـث الثالـث فجـاء فيـه دراسـة في الأحوال الاقتصادية لمدينة عبادان. المبحث الأول: لمحة جغرافية لمدينة عبادان :

قبـل البحث بجغرافيـة مدينـة عبـادان نبـين مسن ايـن جـاء الاسـم الـني اطلـق على المدينـة ، عبـادان تـأتي بمعـان عـدة فهي تعنـي العبـد الحـر او العبـد الرقيـق او تـأتي

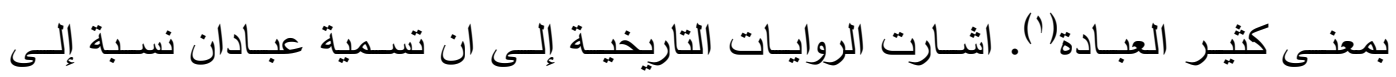

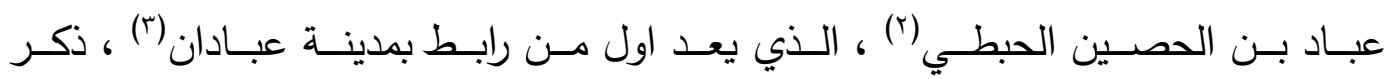

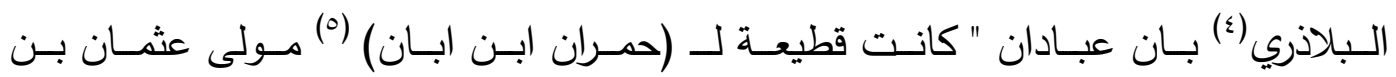
عفان (رضي الله عنه) ، اقطعه إياه الخليفة عبد الملك بن مروان ، ... " . 


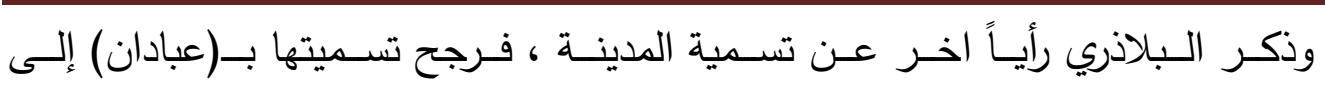

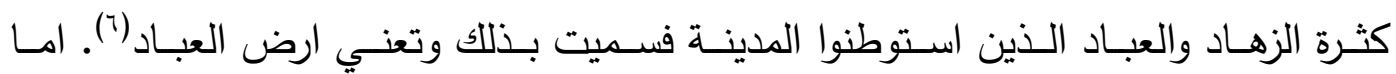

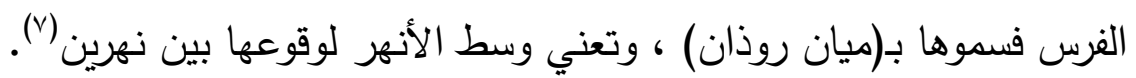

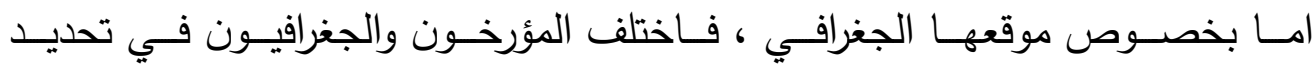

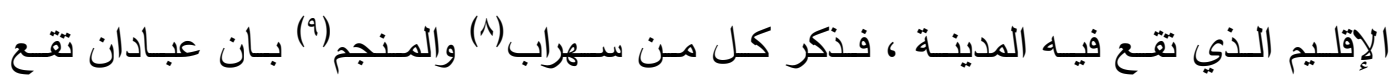

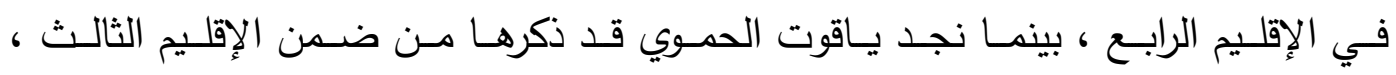

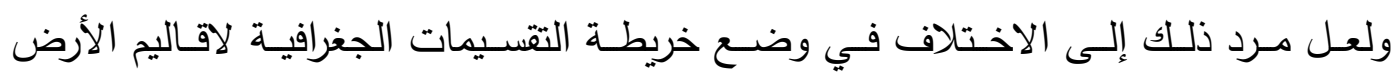

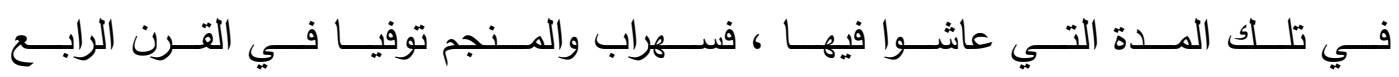

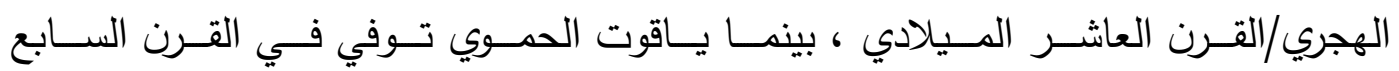
الهجري/القرن الثالث عشر الميلادي.

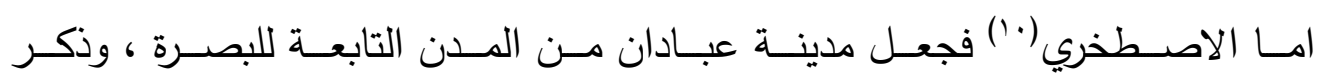

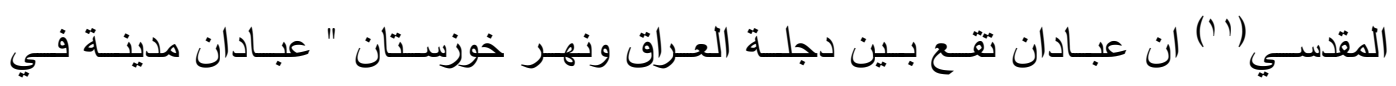

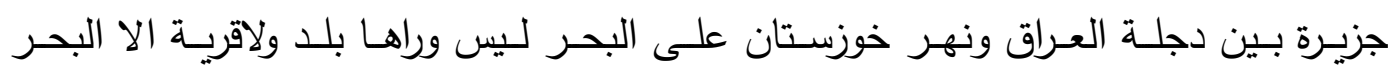
وعبادان من هذه كورة هي من العراق ".

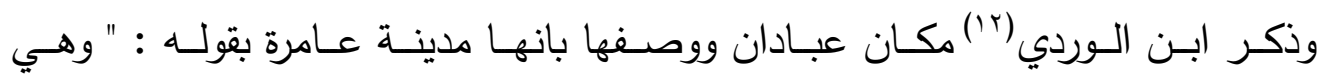

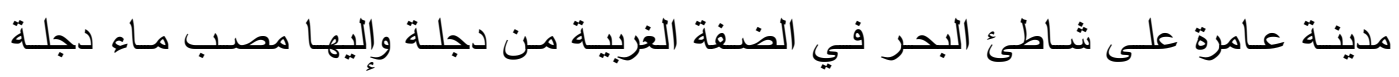
ويقال في المثل ما بعد عبادان قرية ".

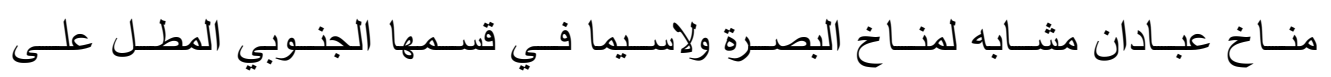

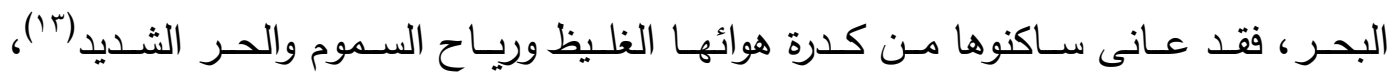

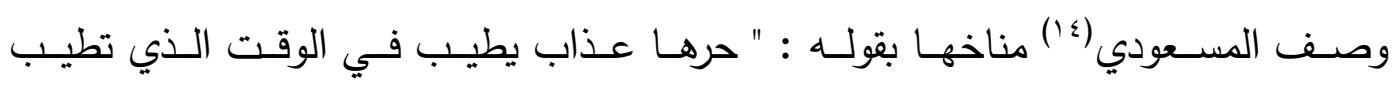

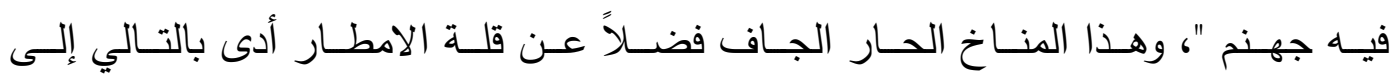

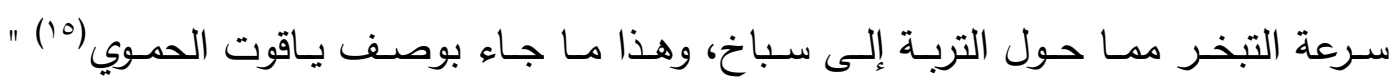

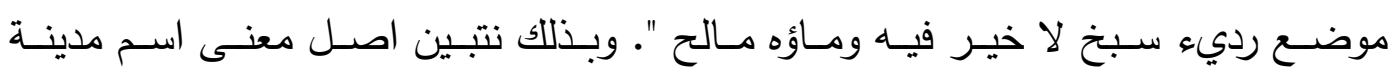
عبادان وموقعها الجغرافي ومناخها الذي كان له تاثير في نوعية التربة وجودتها. المبحث الثاني: الأحوال السياسية لمدينة عبادان:

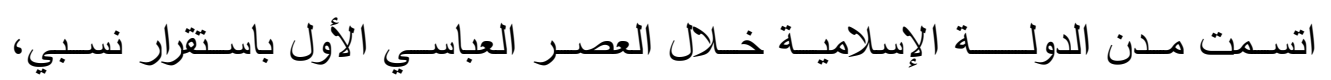

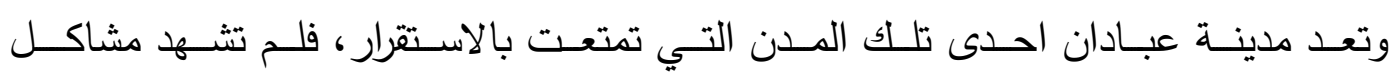

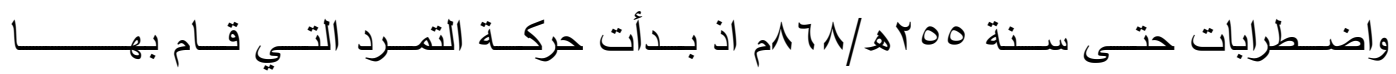

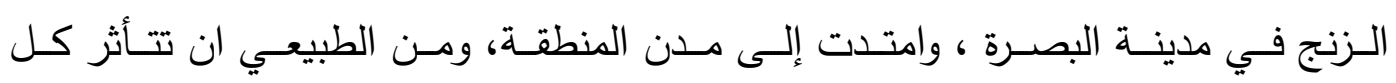

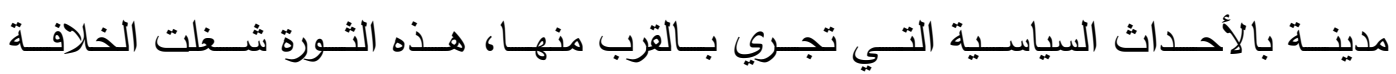




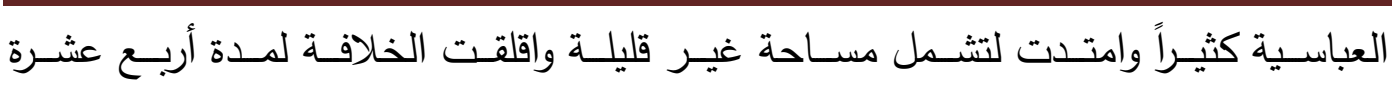

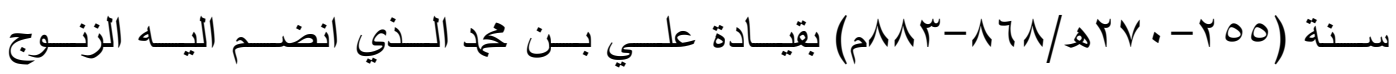

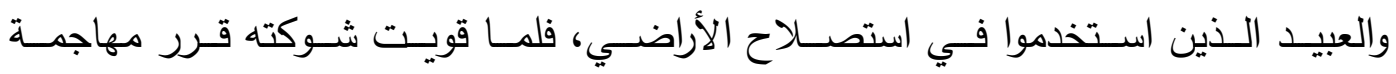

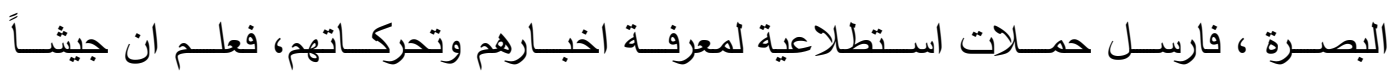

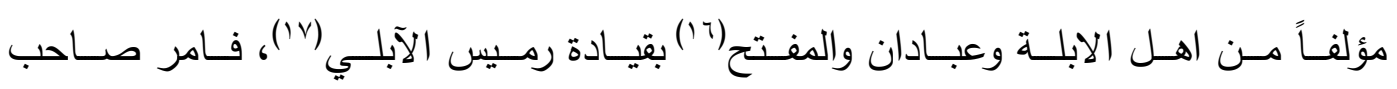

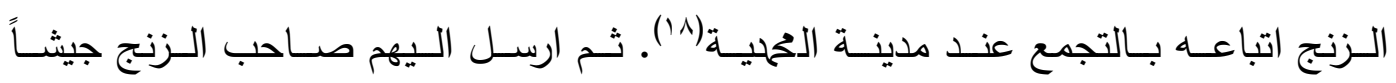

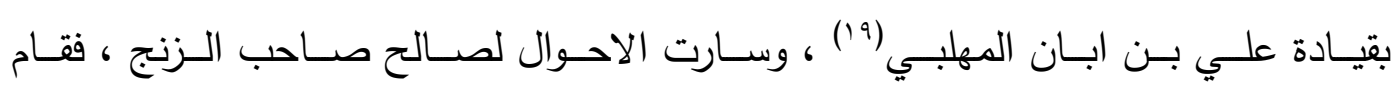

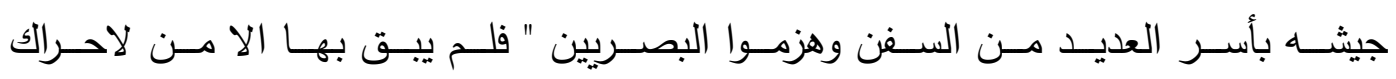

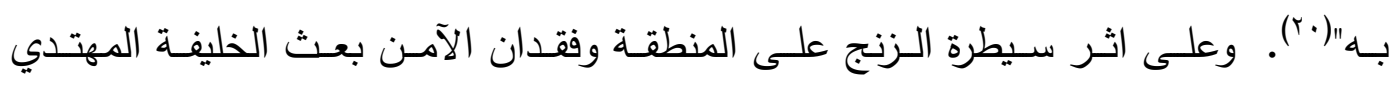

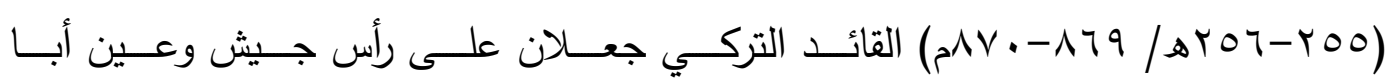

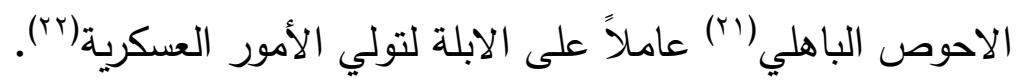

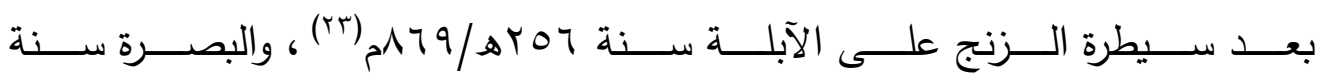

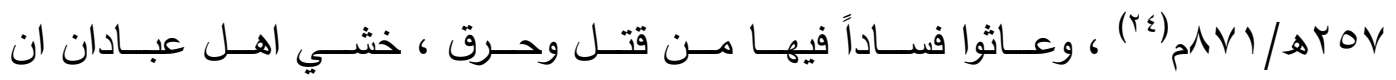

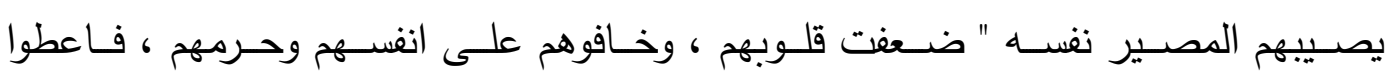

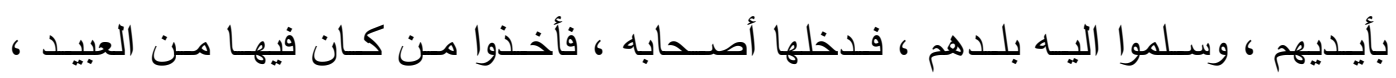

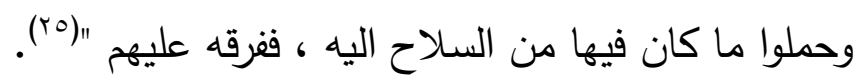

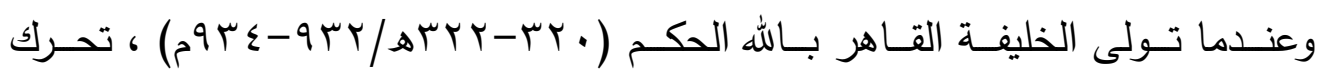

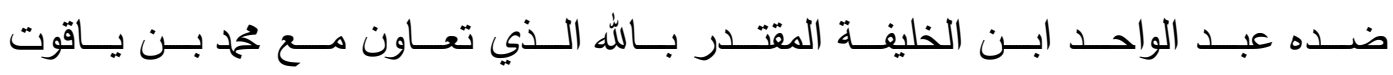

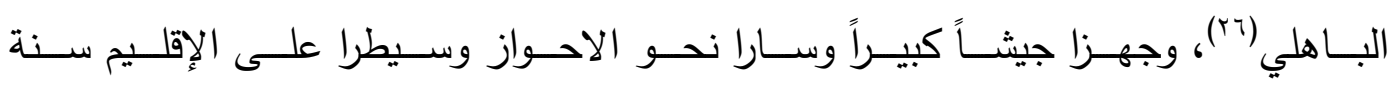

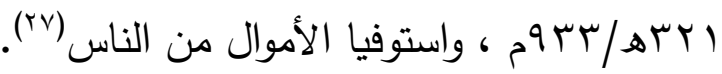

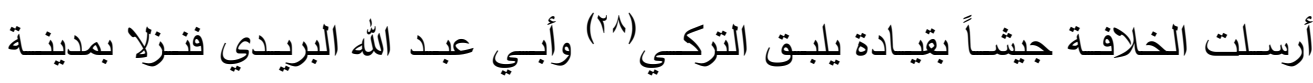

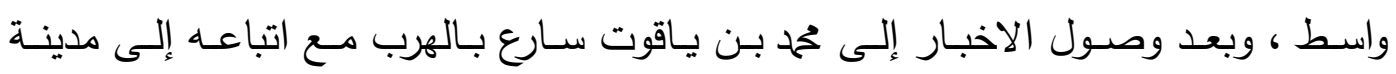
تستر (ra) ، ثم سيطر البريديون على عبادان واتبعوا سياسة شديدة مع اهلها (r.).

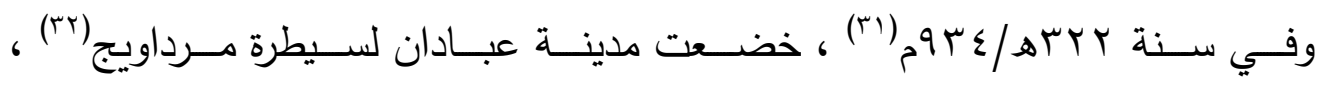

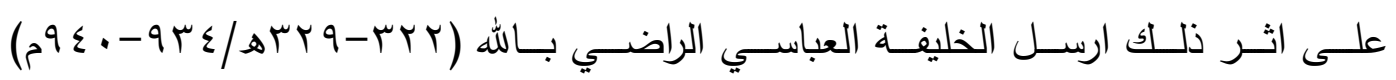

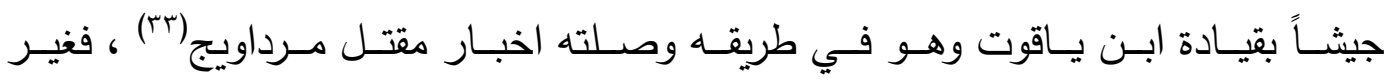

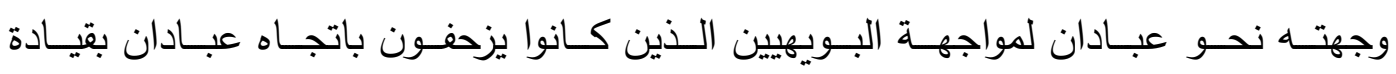
علي بن بويه(๕). 


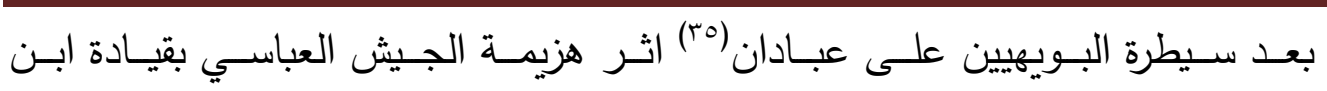

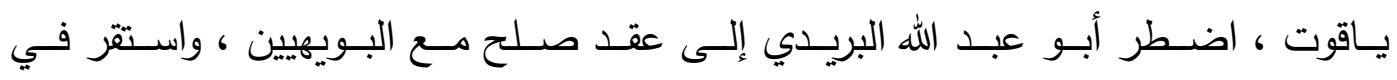

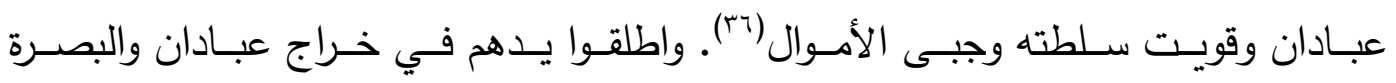

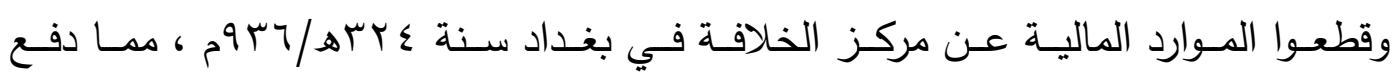

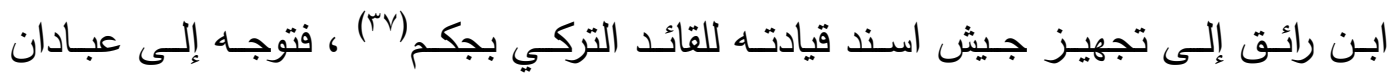

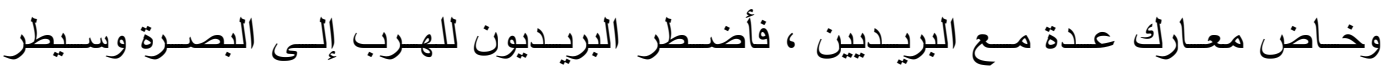

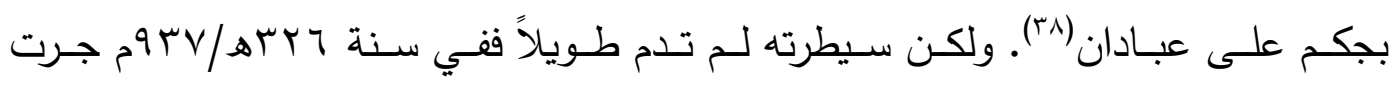

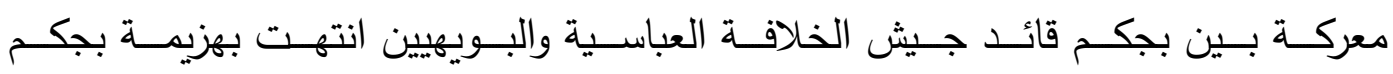
ورجوعه إلى بغداد ، واستيلاء البويقيين على عبادان(ج9).

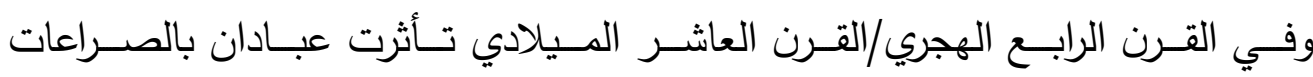

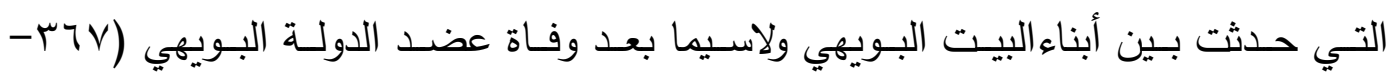

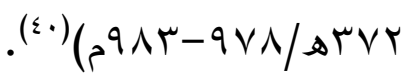

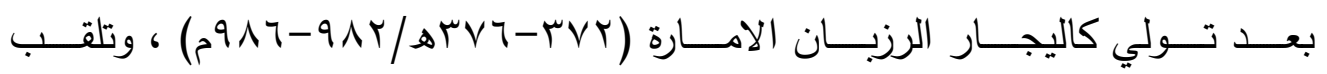

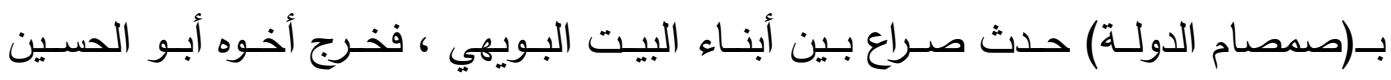

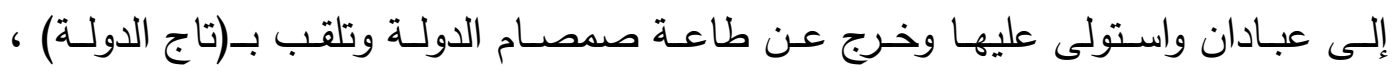

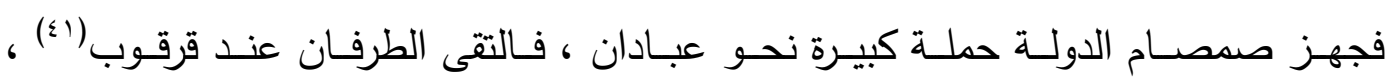

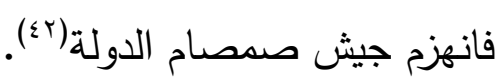

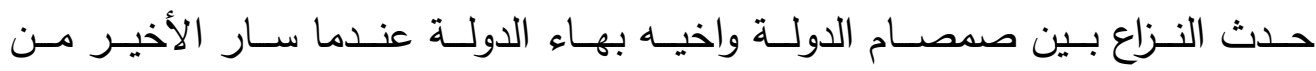

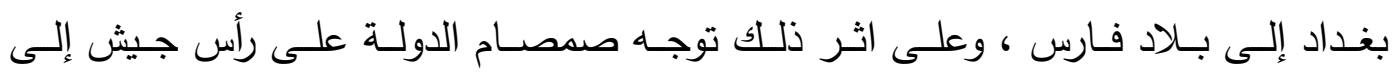

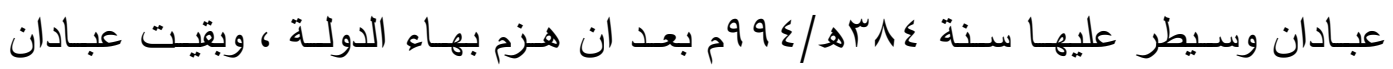

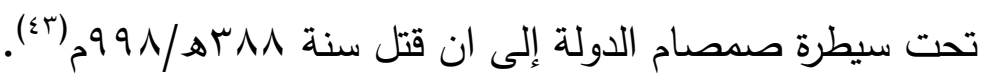

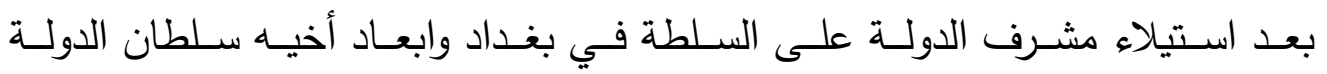

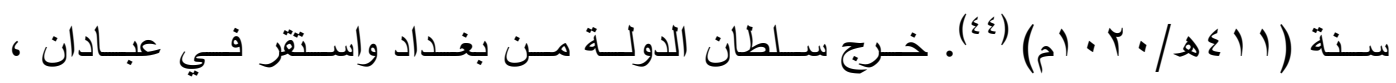

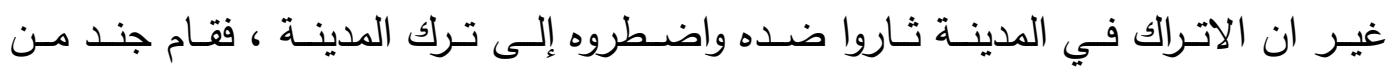

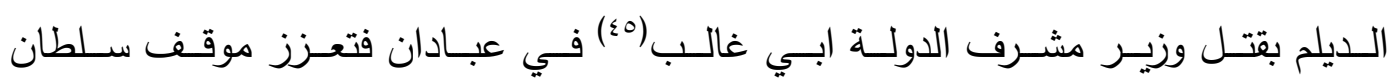
الدولة ، فأرسل ابنه أبا كاليجار واستولى على عبادان (بـ).

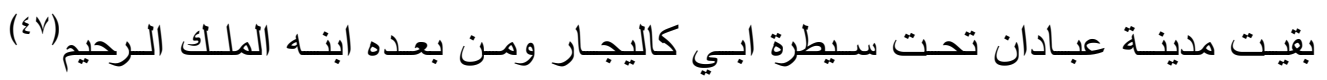

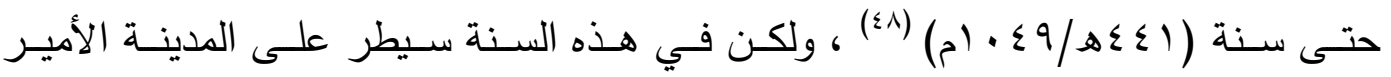

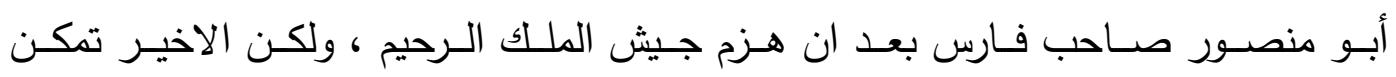

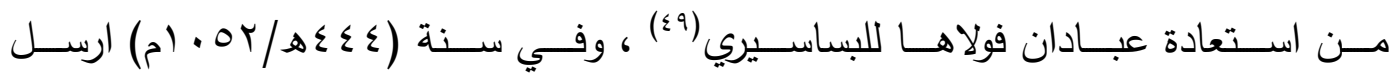




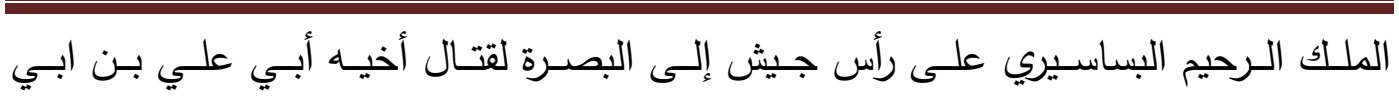

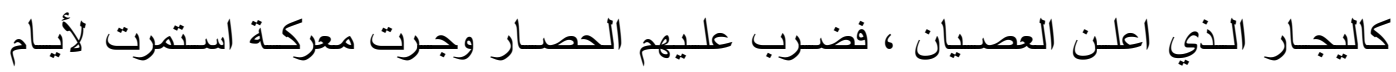

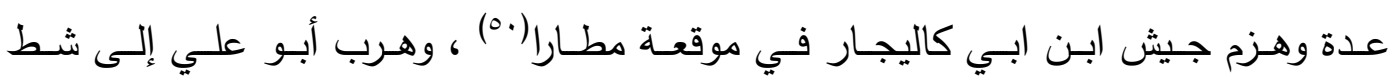

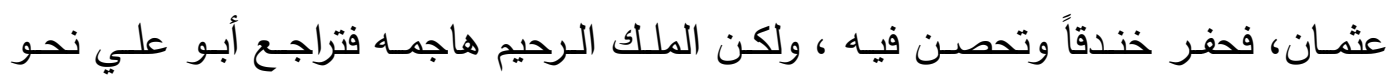

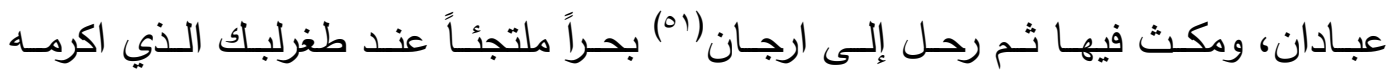

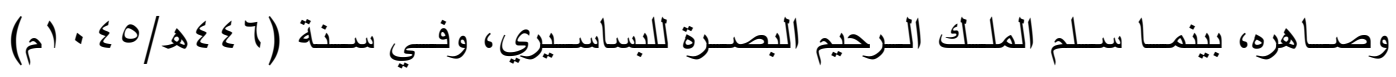

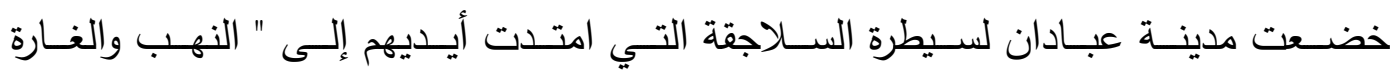
والمصادرة ولقي الناس منهم عنتا وشدة "(or).

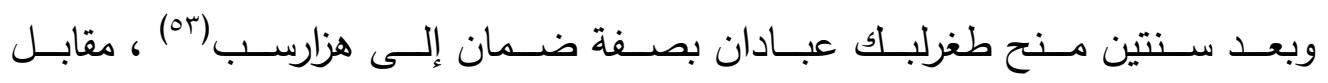

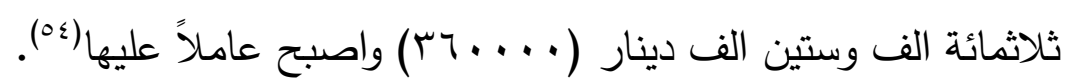

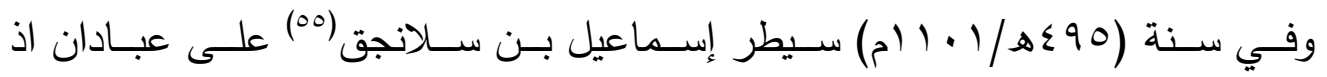

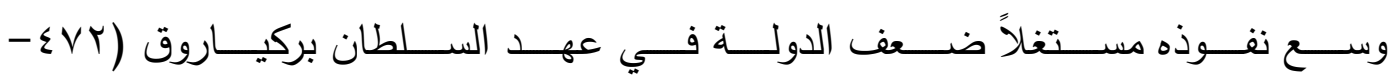

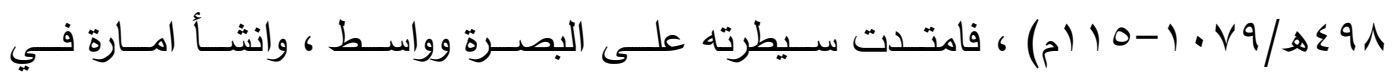
البصرة ضمت هذه المناطق (07).

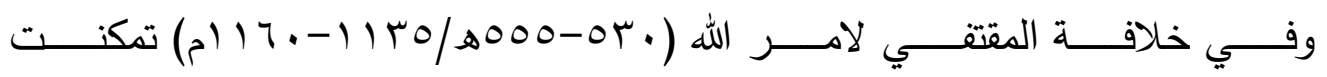

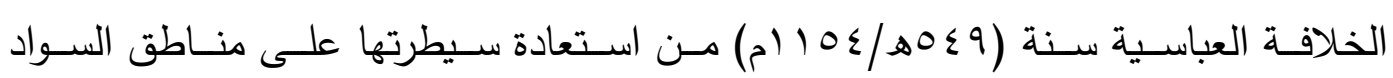
ومنها عبادان (ov).

\section{المبحث الثالث: الأحوال الاقتصادية لمدينة عبادان :}

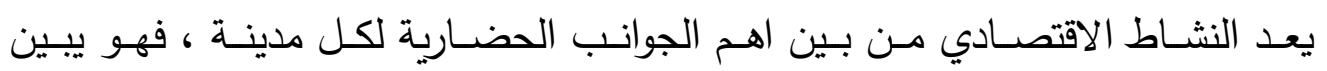

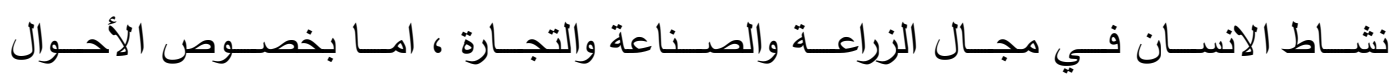

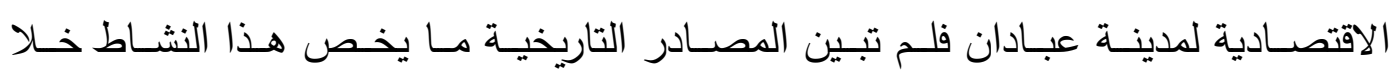

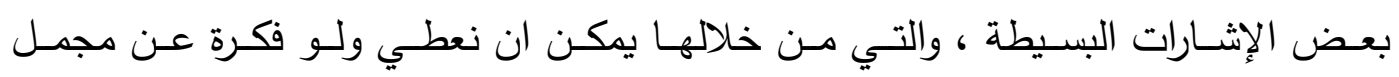

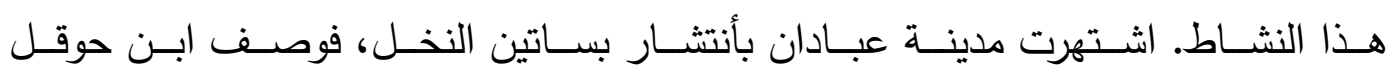

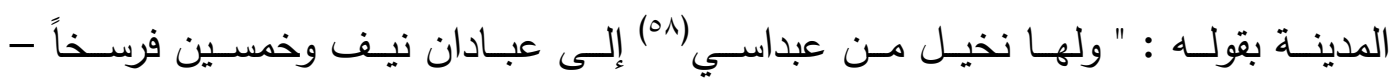

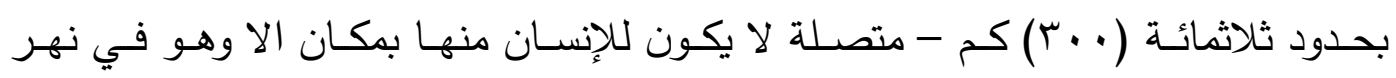

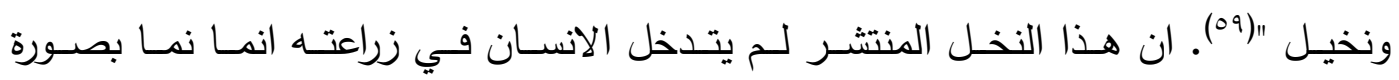

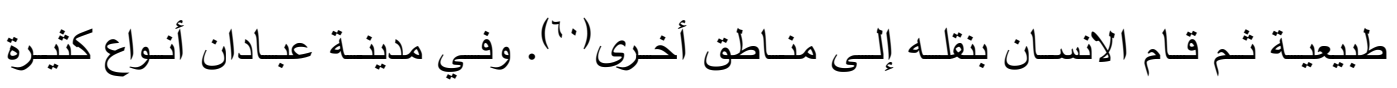
من التمور (11). 
اشـتهرت مدينـة عبـادان بثروتهـا الحيوانيـة فأشـتهرت بتربيـة بعـض الحيوانـات ذات

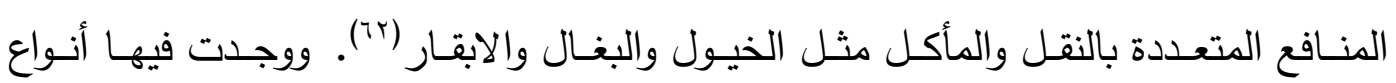
مـن الطيور ، أشـار لـللك ابـن خرداذبـة بقولـه : " فيـه الطير تجمـع مـن قذـى البحر عند

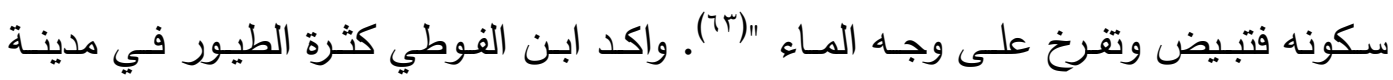

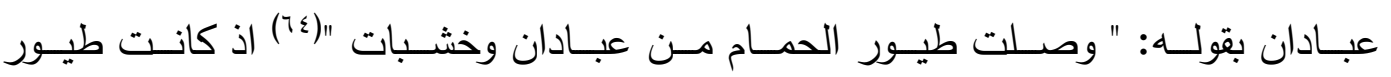
الحمام تهاجر من عبادان إلى الكوفة (70).

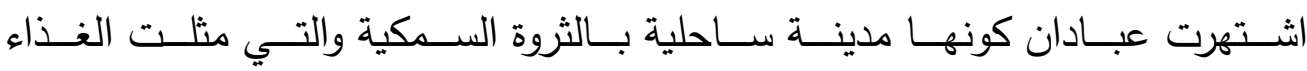

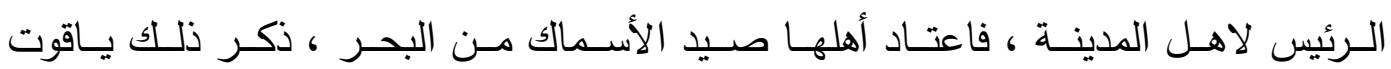
الحموي(ז7) بقوله : " واكثر اكلهم السمك الذي يصيدونه من البحر ". واتبـع اهـل عبـادان حيـل فـي اصــيادهم للاســماك ، فكـانوا فـي موســم صـيد

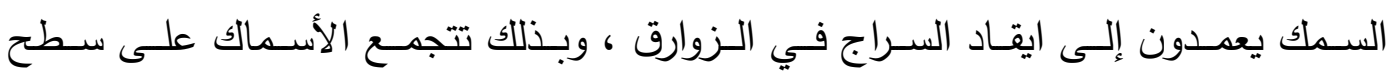

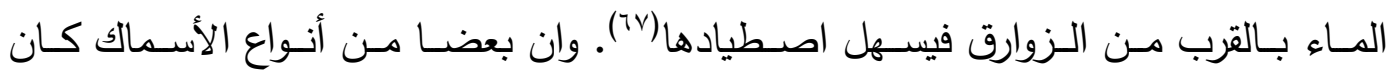
كبيراً وطوله يتجاوز الامتار (^^). امـا بخصـوص النشـاط الصـناعي في مدينـة عبـادان ، فأشتـهرت بصـناعات عـدة،

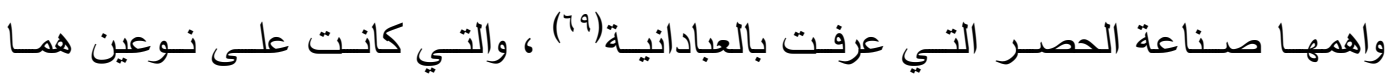
الحصـر العبادانيـة والحصـر السـامانية(•) ، التـي كانـت تصــنع مـن الحلفـة " واكثـرهم صناع الحصر من الحلفاء"(V) وبـين النـويري جمـال حصـر عبـادان بقولـهـ : "وبهــا مـن الحصـر العبـداني ومـن سـائر أصـناف الحصـر مـا لا يوجـد في غيرهـا "(VY). ولجمالهـا وجودتهـا فاقـت شـهرتها ووصــلت إلـى الأقـاليم حتـى قلـدت فـي مصــر وفـارس(Vr). وفضــلاً عــن الحلفــاء

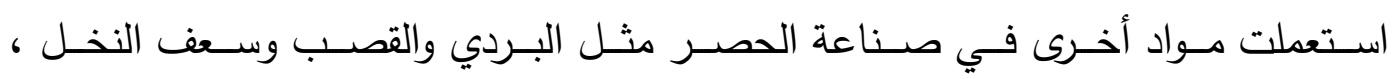
والتي امتهنها اهل عبادان(ع (V). ولكثرة انتشـار النخـل في المنطقـة ومنهـا مدينـة عبـادان راجـت صــاعة الـدبس ،

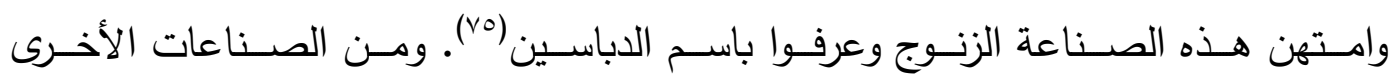
التـي راجـت في مدينـة عبـادان هـي صــاعة نـوع مـن الخفـاف يســـى المـوق ويجمـع على امواق، وهو خف غليظ يلبس فوق الخف ، كان اهل عبادان يلبسونها(VT).

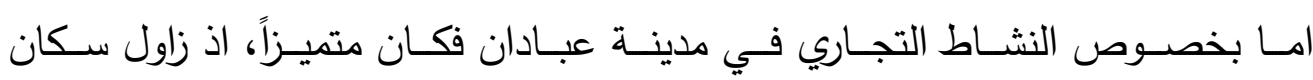

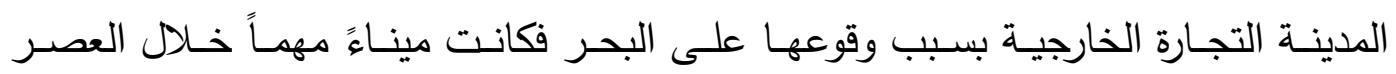

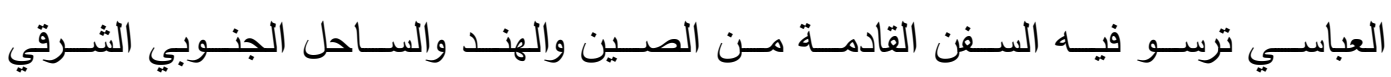
لافريقيا، فضلاً عن سفن البحر الاحمر (vv). 
عنيــت الدولــة العربيـة الإنسـلامية فـي العصـر العباسـي بالنشــاط التجـاري عـن

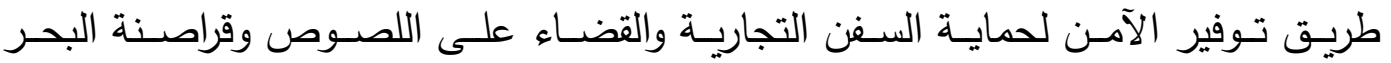

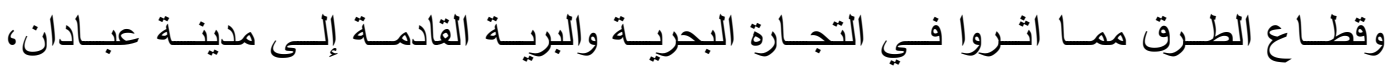

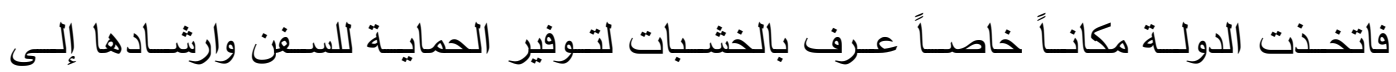

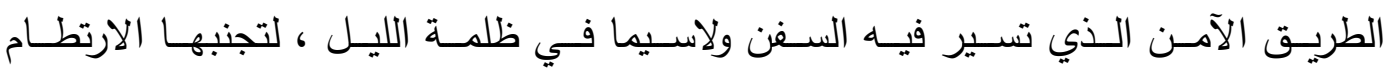

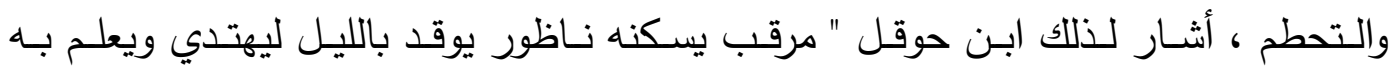

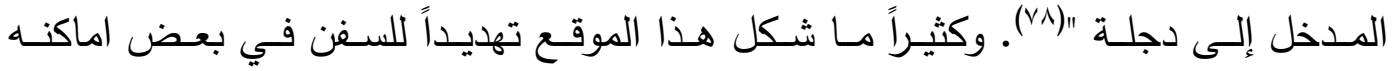

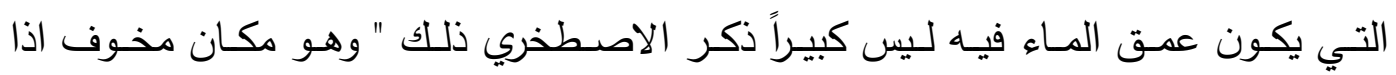

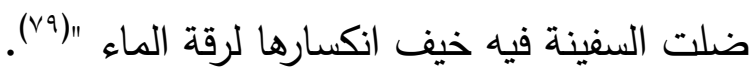
كـان مـن عوامـل ازدهـار النشـاط التجـاري فـي العصـر العباسـي ازديـاد مظــاهر

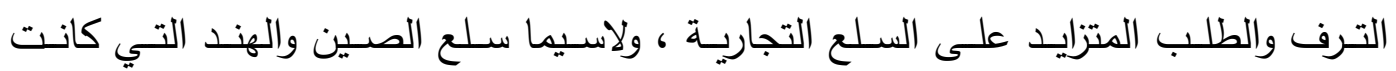

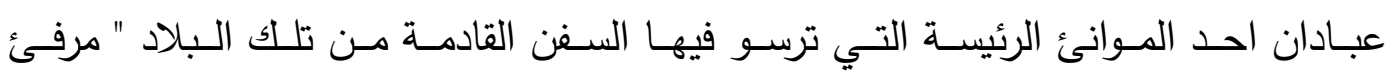

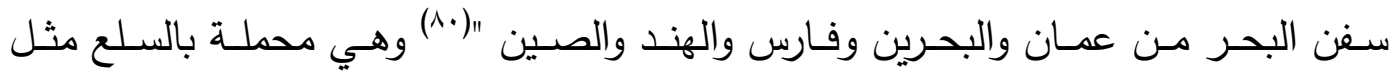

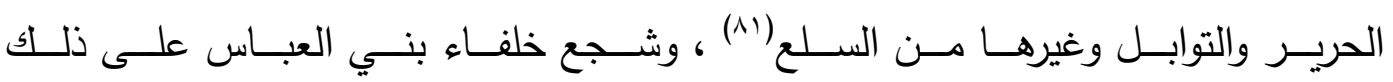

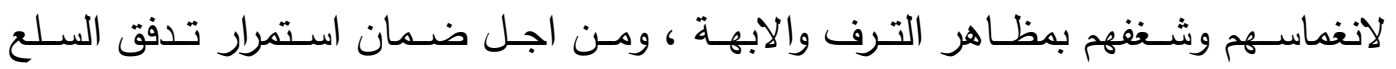

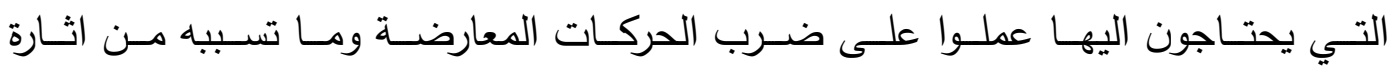

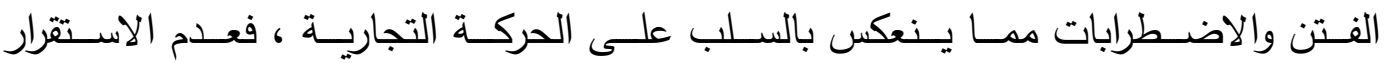
يمثل تهايداً حقيقياً لأمن التجار (Ar).

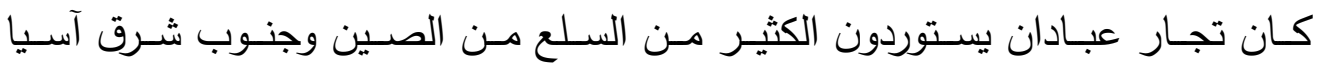

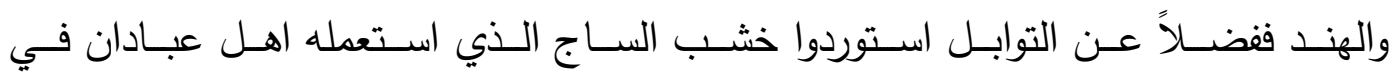

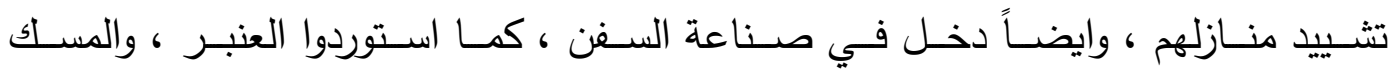

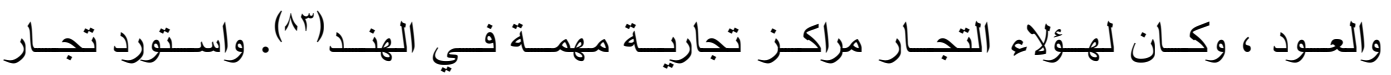

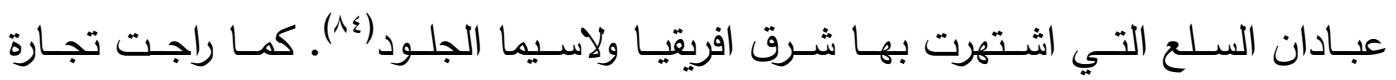

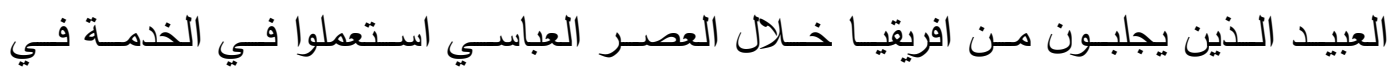

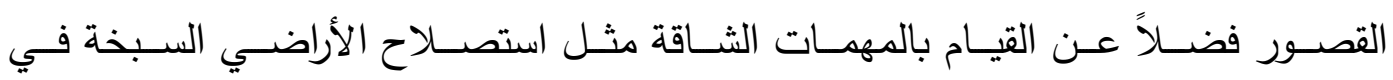
السواد ومنها عبادان(1) (1).

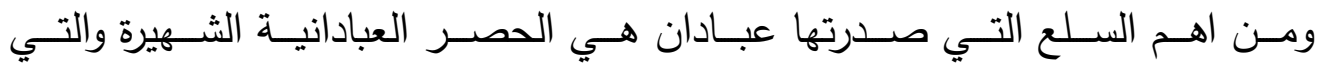

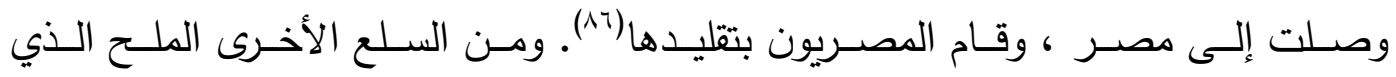

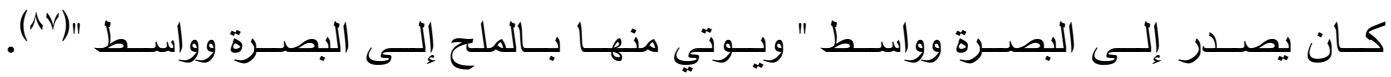




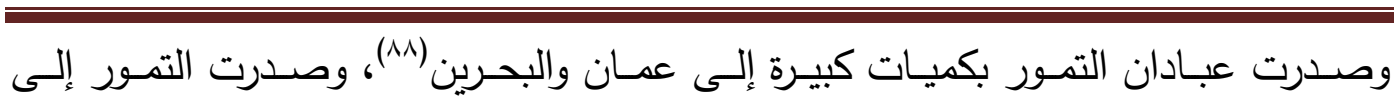

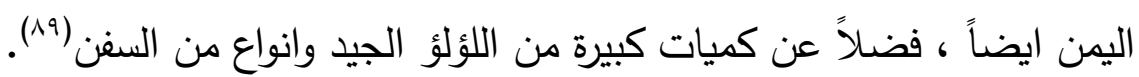

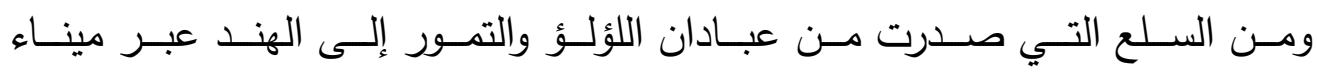

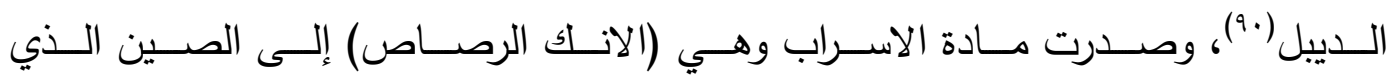

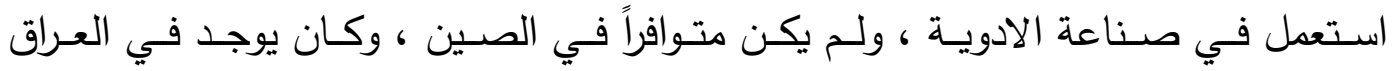

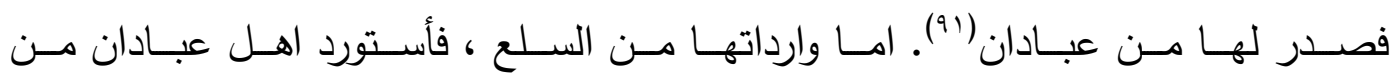

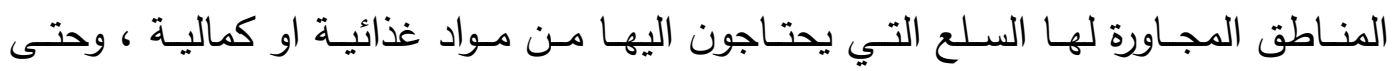
مواد صناعية مثل الاخشاب والجلود (rar).

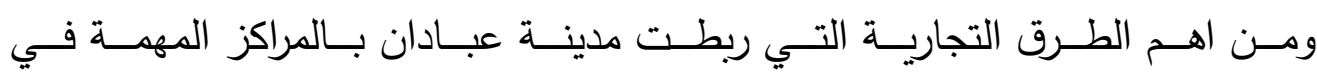

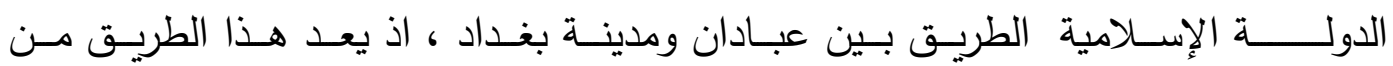

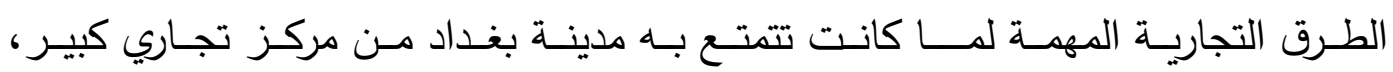

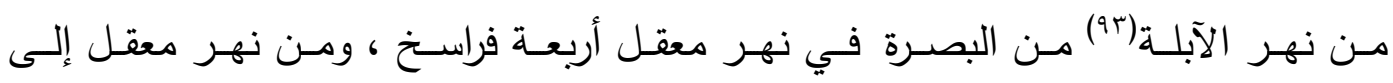

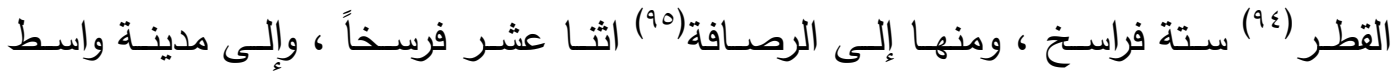

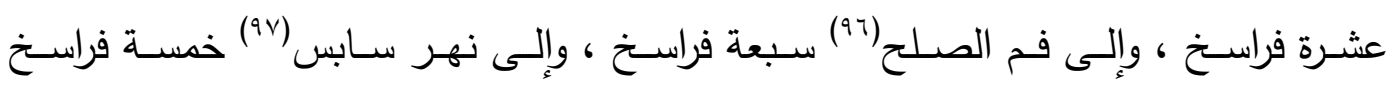

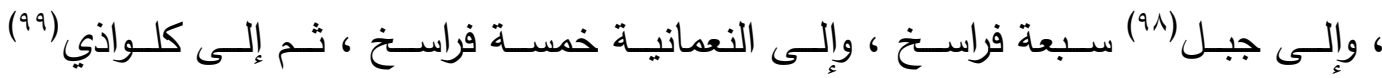

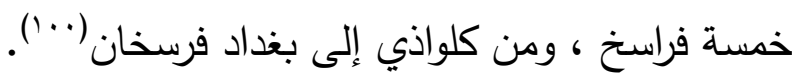
وتوجد طرق عدة ربطت مدينـة عبادان بالبصـرة ، وهي ثلاثـة طرق منطلقها مـن

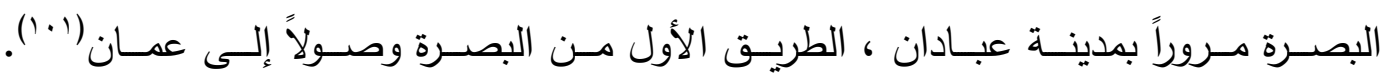

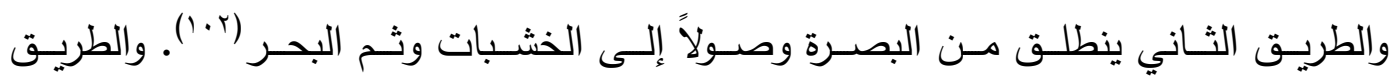

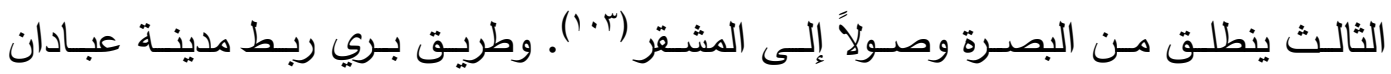

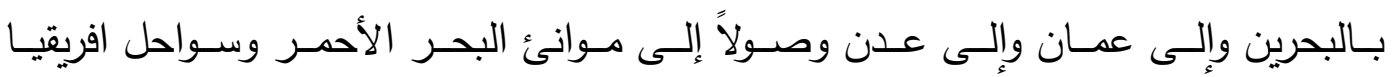

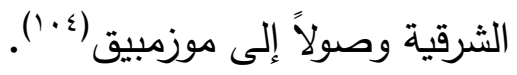

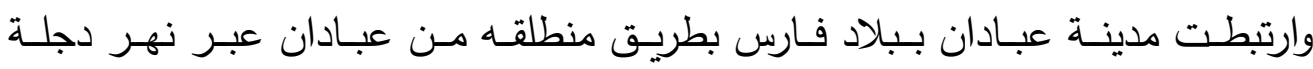

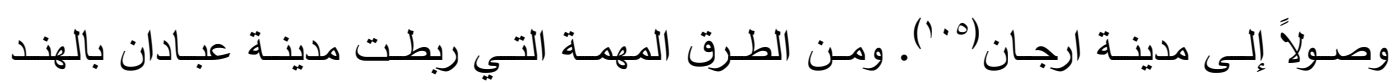

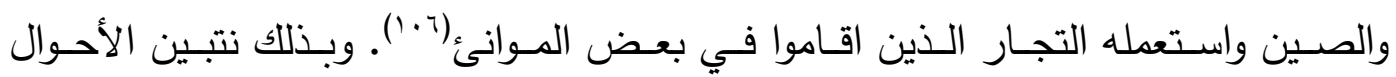

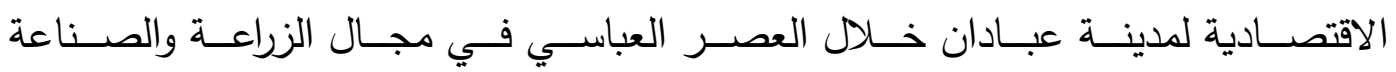
والتجارة ، واهم الطرق البرية والبحرية التي ربطت المدينة بالمناطق المجاورة. 
نتبـين مـن البحـث الموسـوم (الأحـوال السياسـية والاقتصـادية لمدينـة عبـادان خـلال

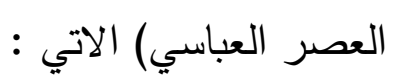

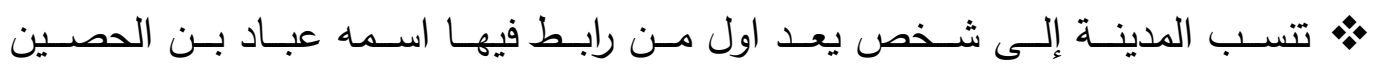

$$
\text { الحبطي }
$$

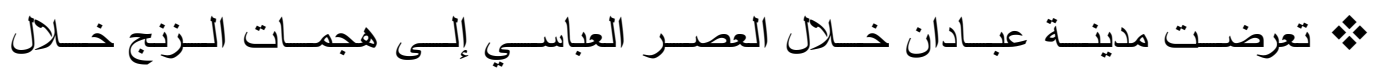

حركتهم التي استمرت لمدة أربعة عشرة سنة.

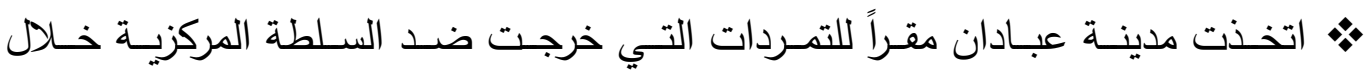

العصر العباسي لحصانة المدينة ولوقوعها بين نهرين.

هـ كـان لمدينـة عبـادان خـلال العصـر العباسـي نشـاط اقتصـادي في مجـال الزراعـة

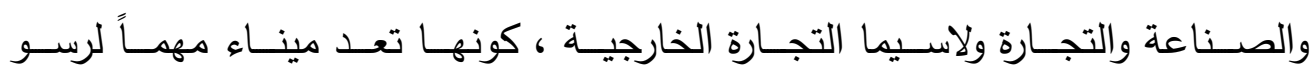

السفن التجارية القادمة من الصين والهند وسواحل افريقيا الشرقية والجنوبية.

الهوامش :

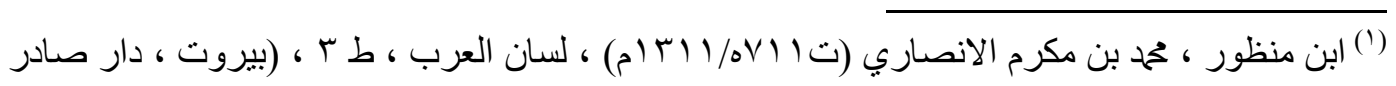
(

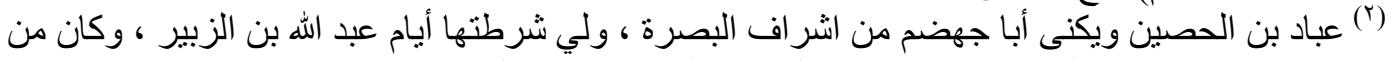

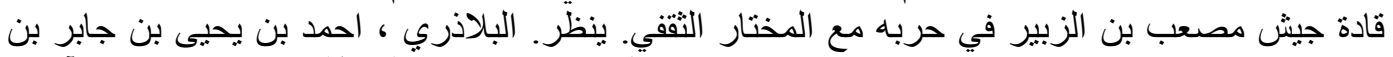

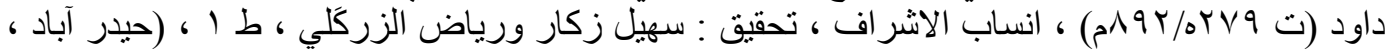

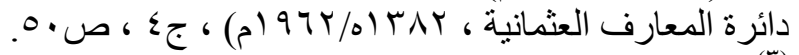

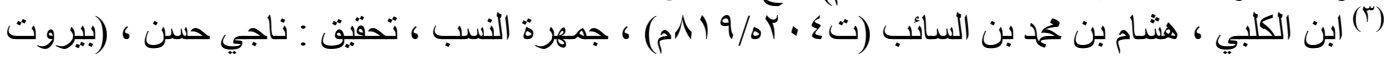

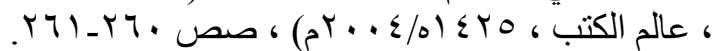

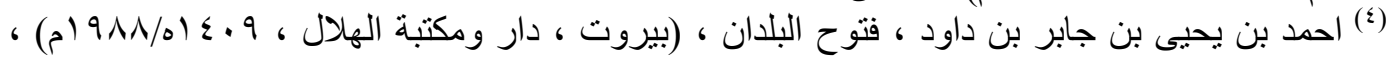

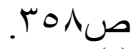

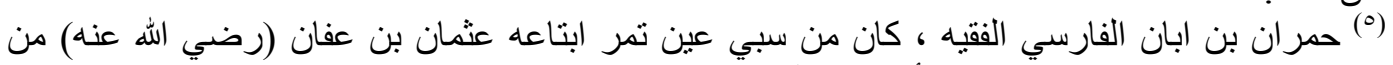

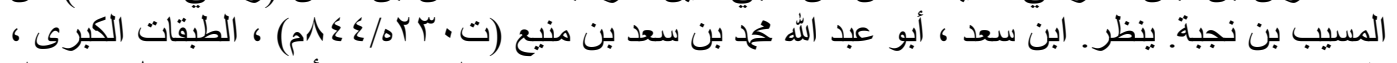

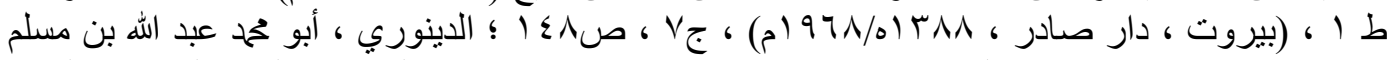

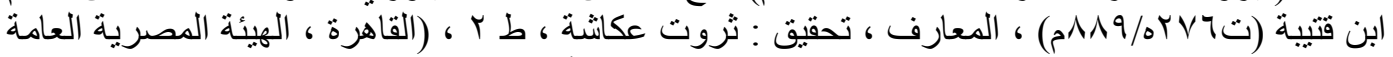

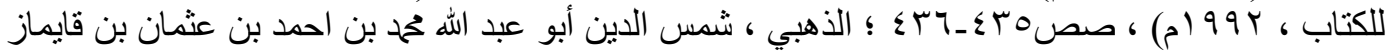

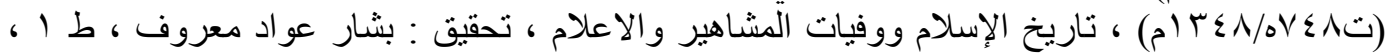

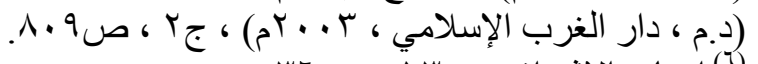

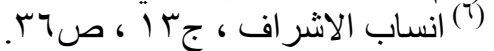

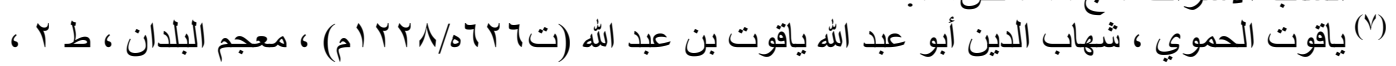

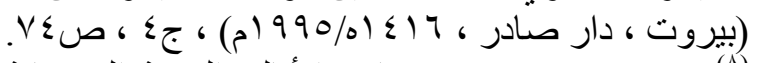

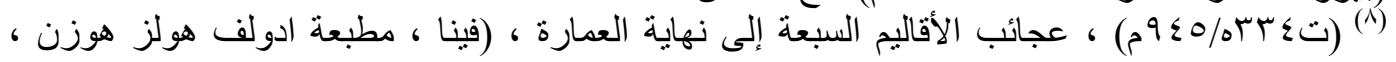
(

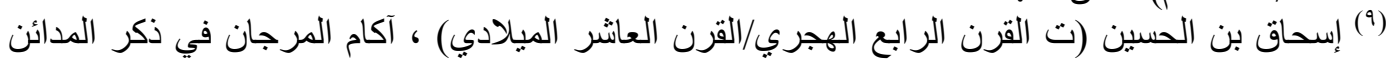

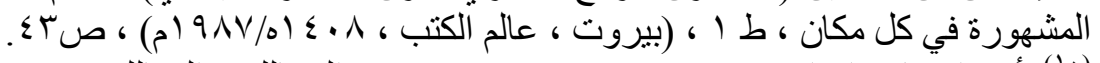

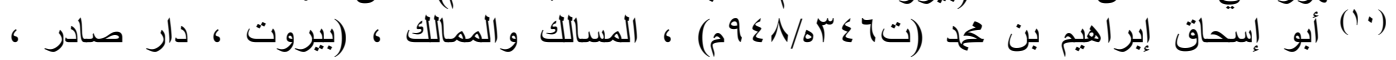

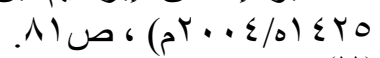

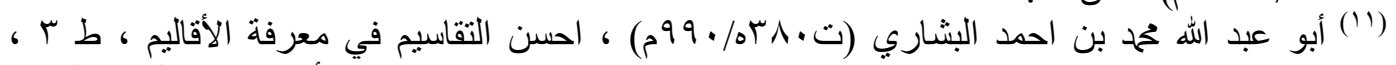

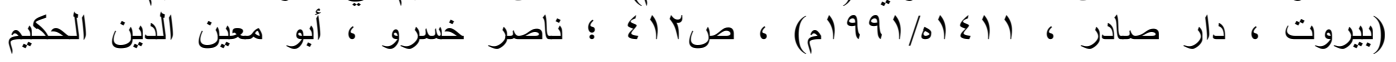




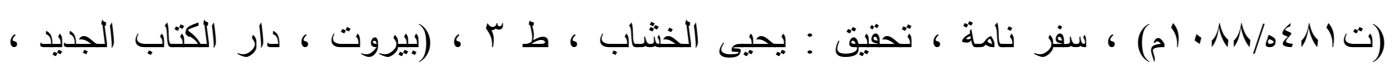

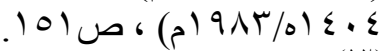

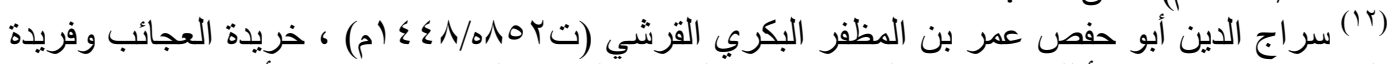

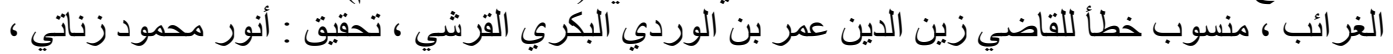

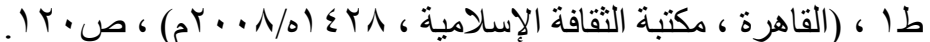

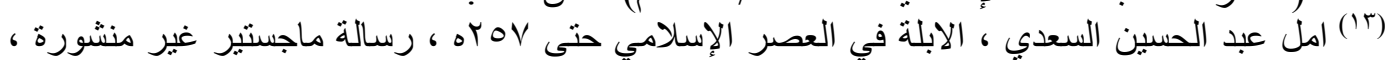

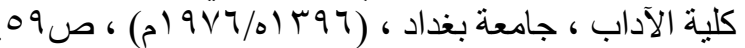

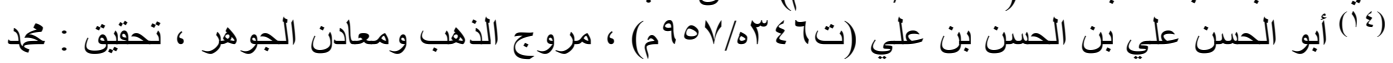

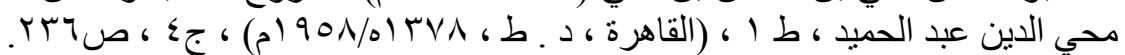
(10)

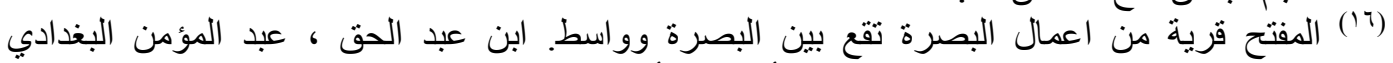

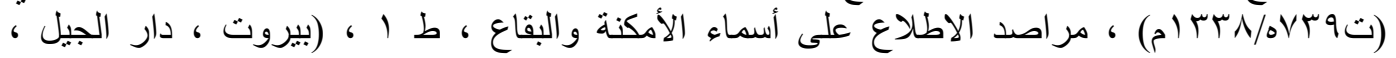
( )

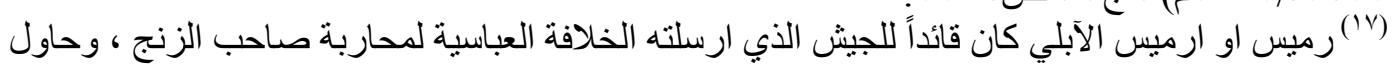

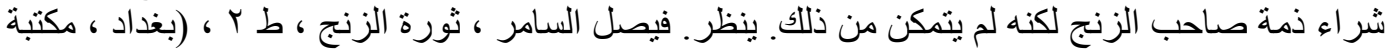

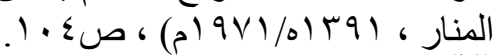

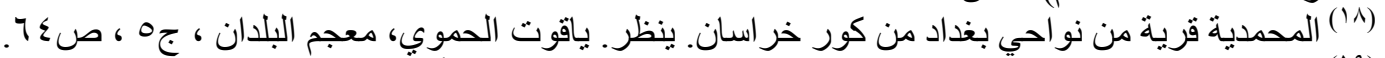

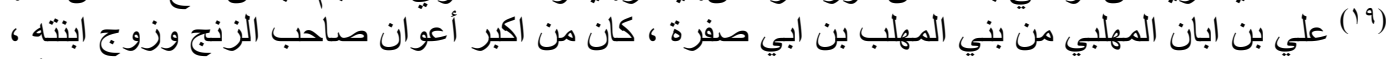

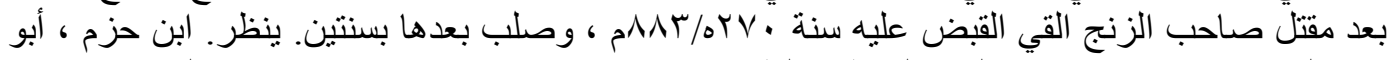

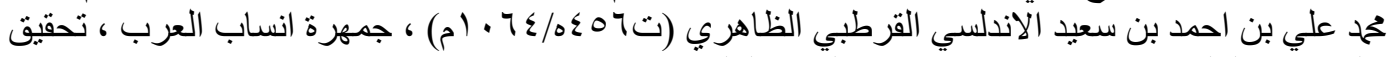

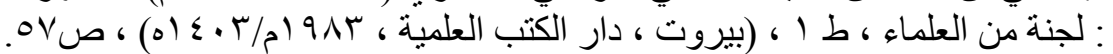

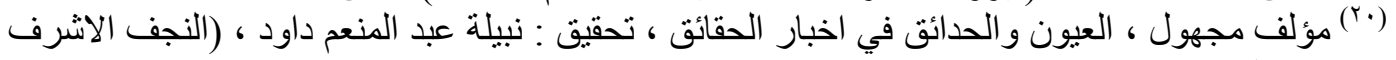

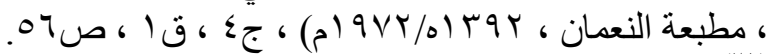

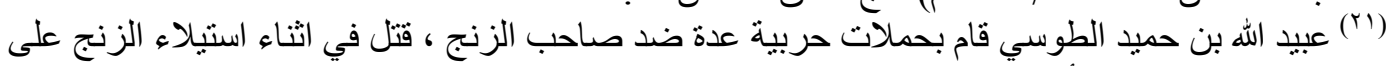

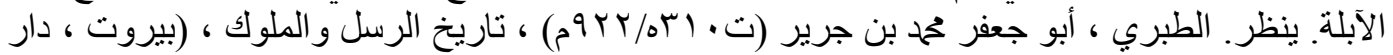

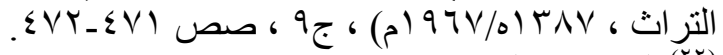

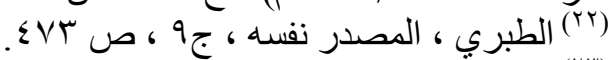

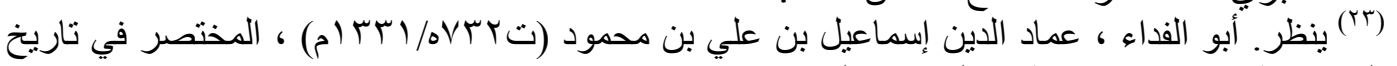

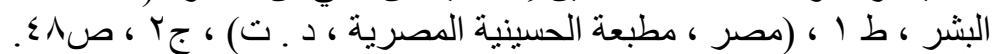

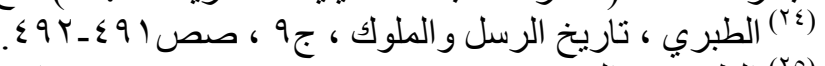

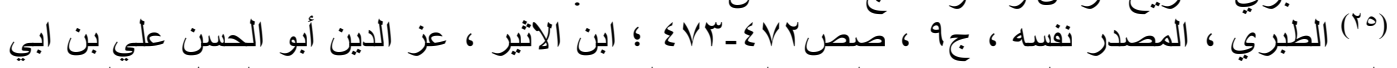

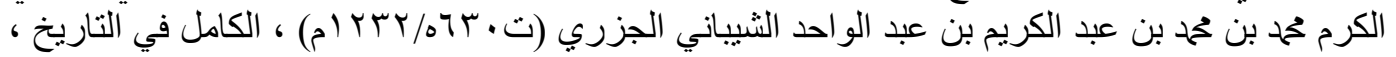

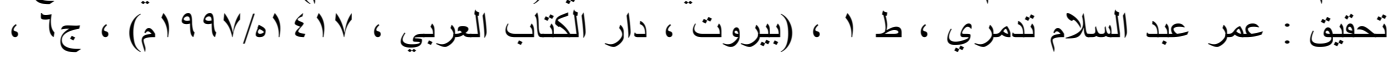

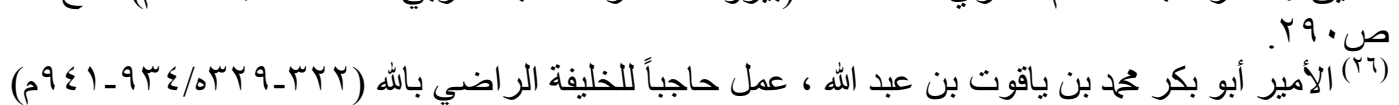

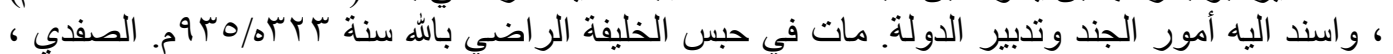

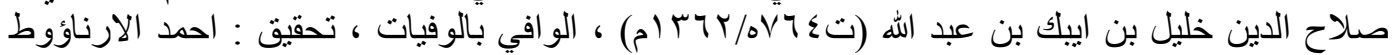

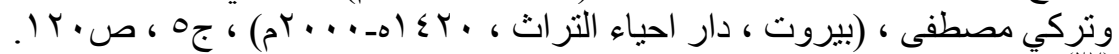

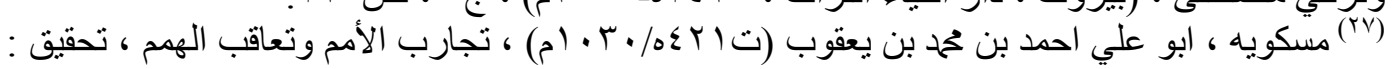

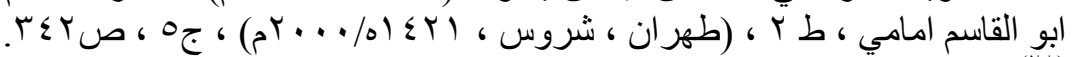

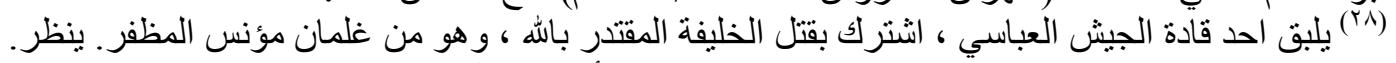

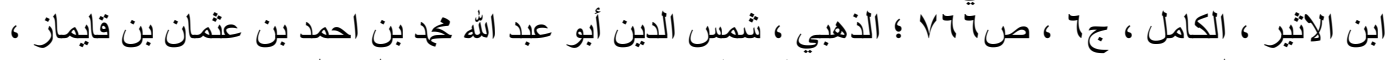

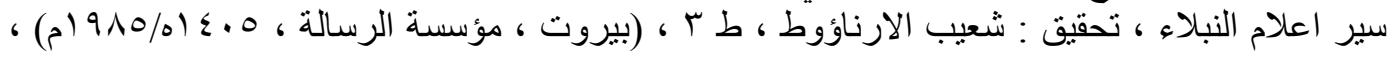

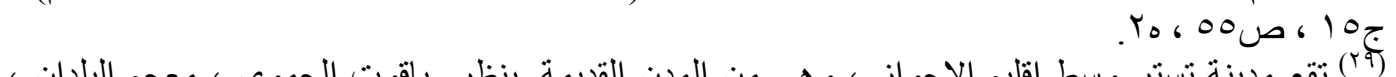

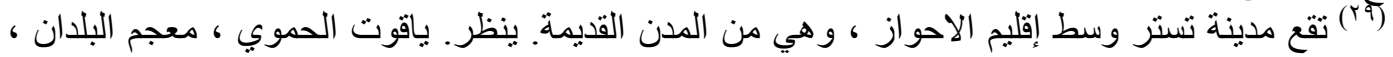

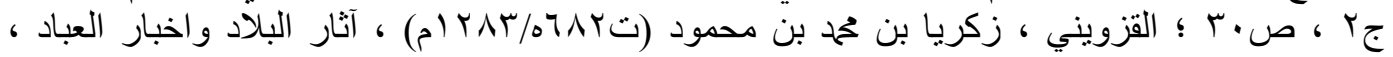

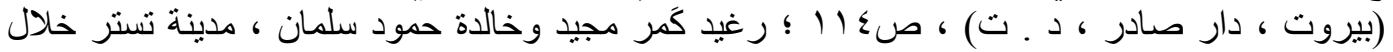

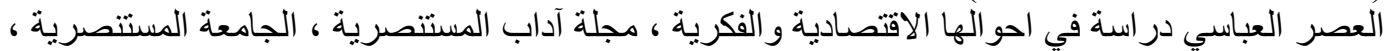

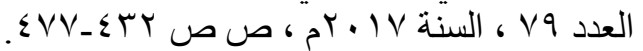

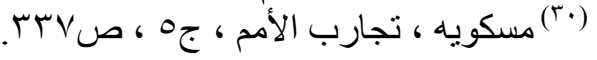


rV

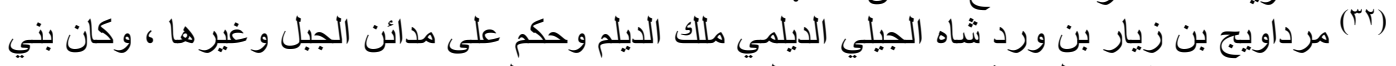

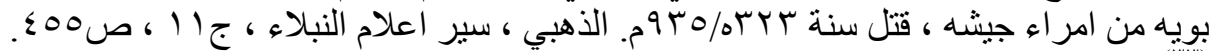

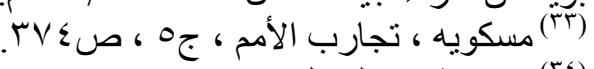

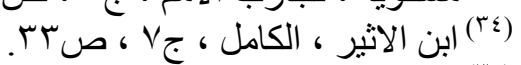

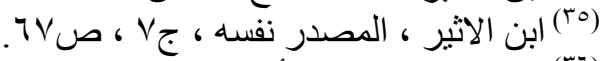

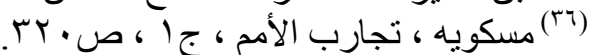

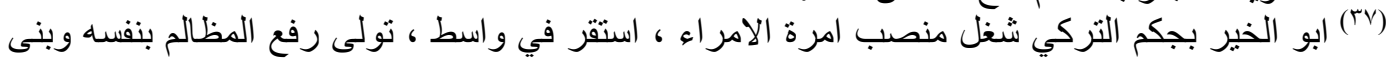

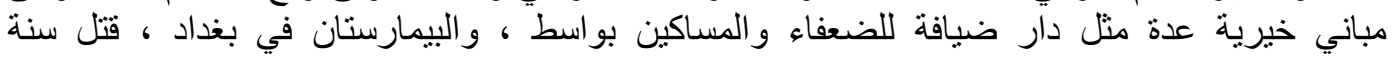

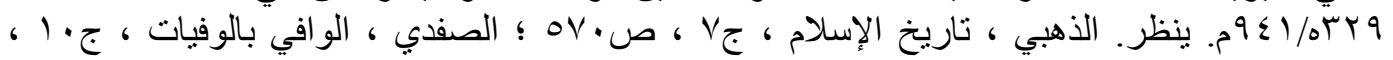
صص

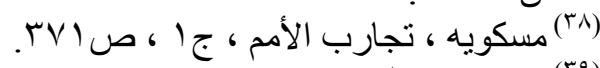

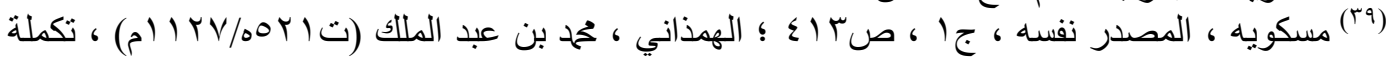

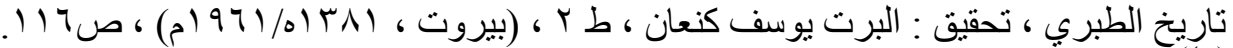

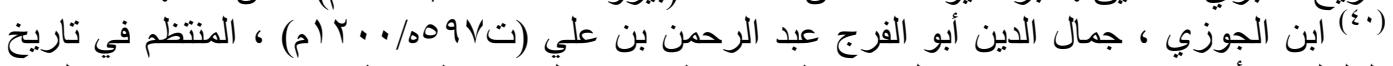

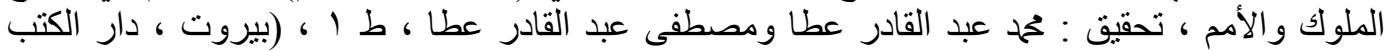

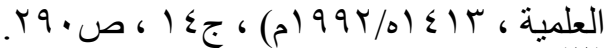

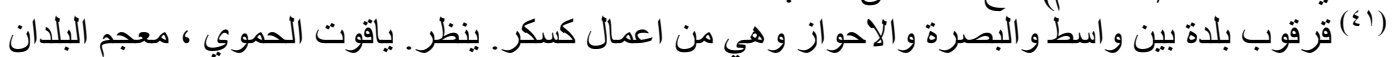

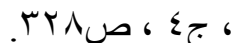

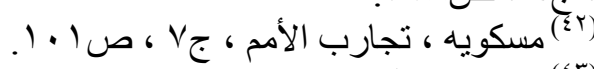

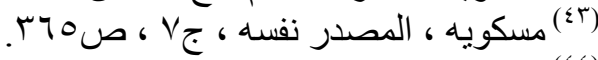

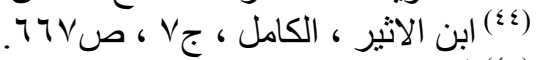

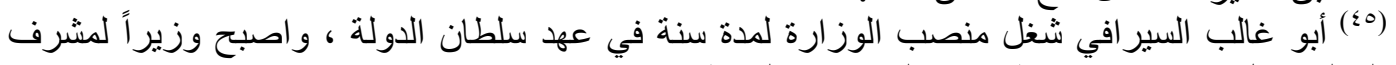

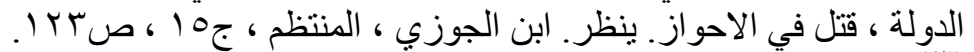

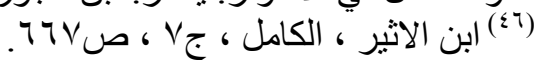

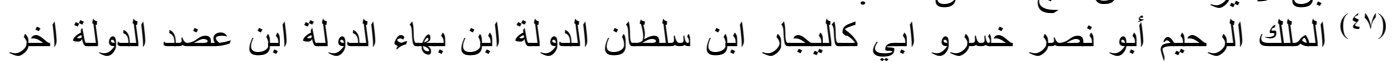

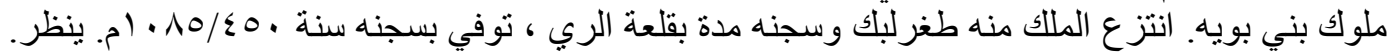

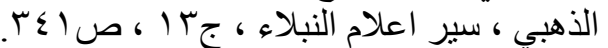

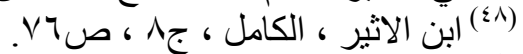

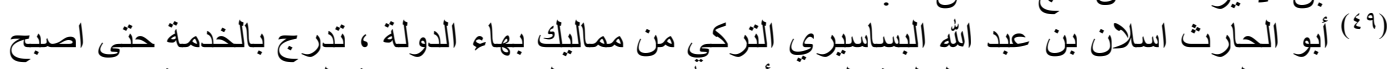

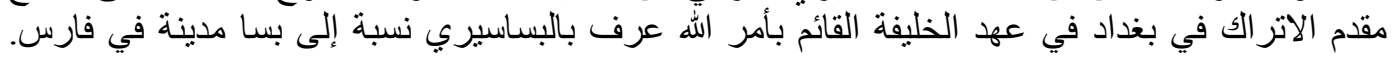

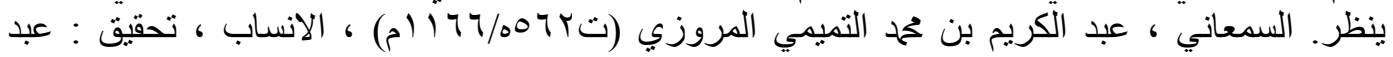

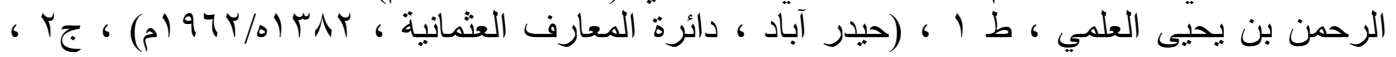

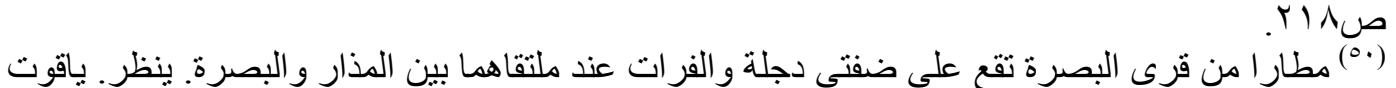

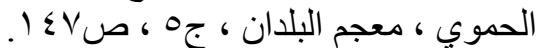

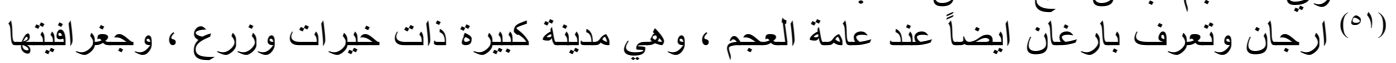

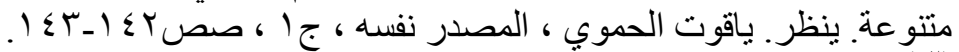

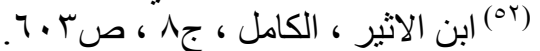

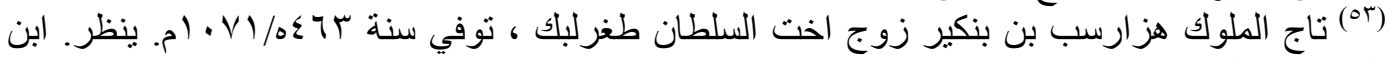

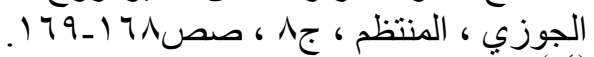

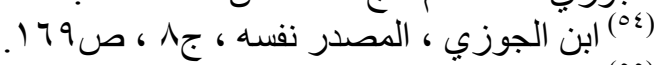

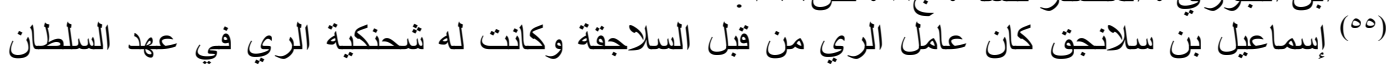

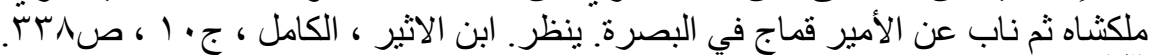

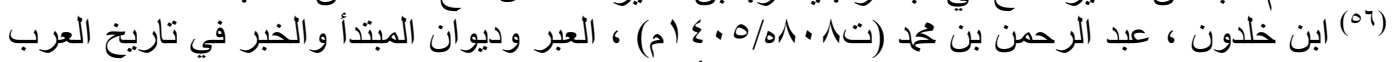

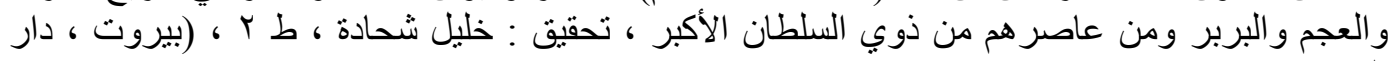

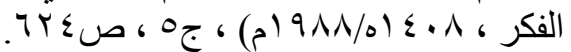

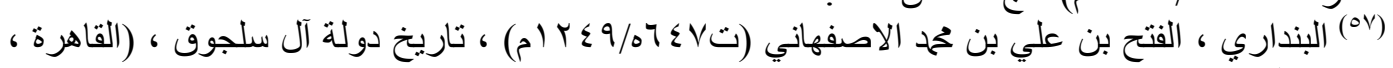

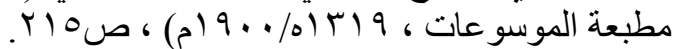

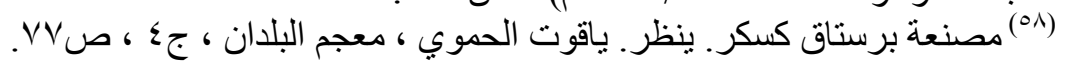




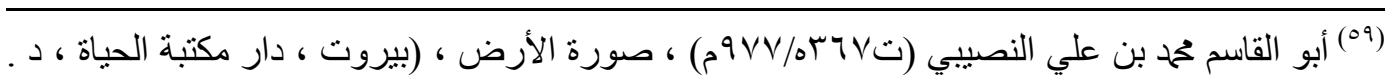

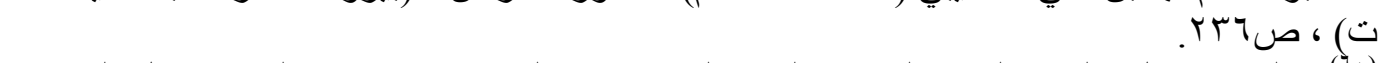

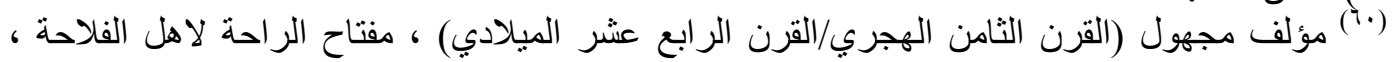

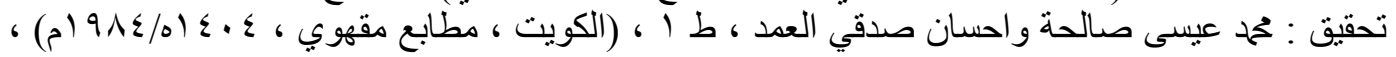
ص9 أ.

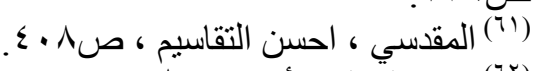

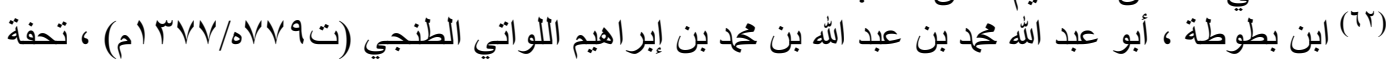

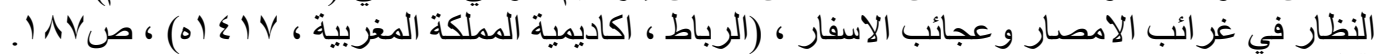

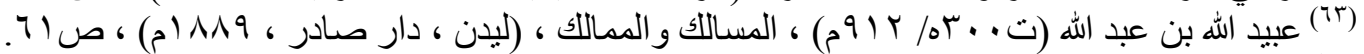

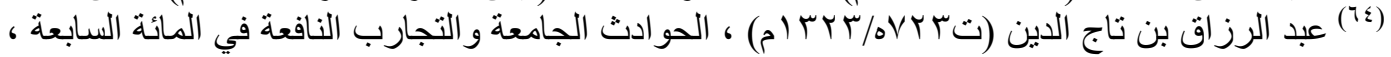

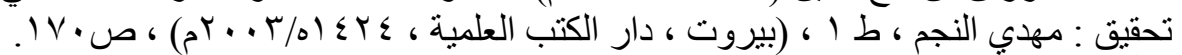

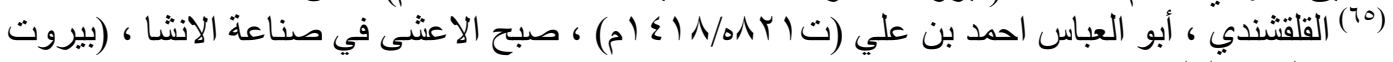

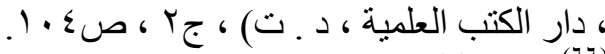

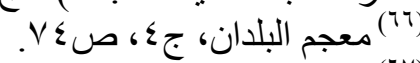

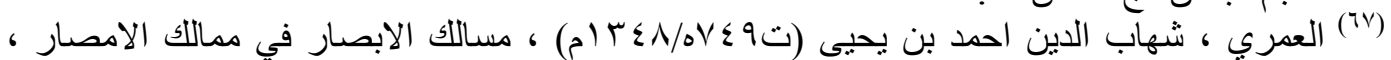

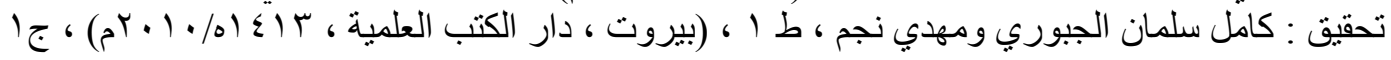

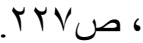

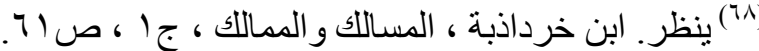

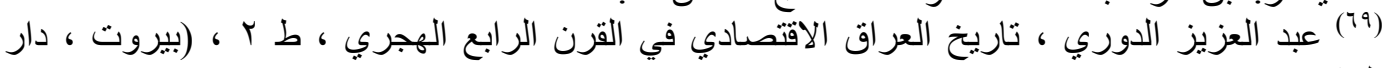

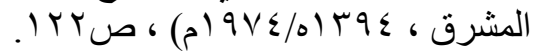

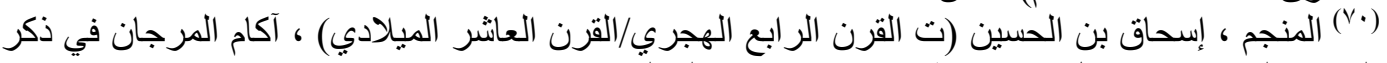

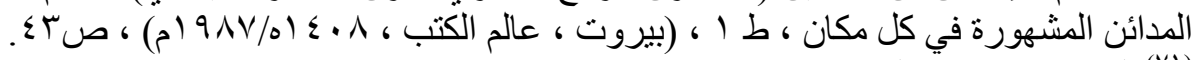

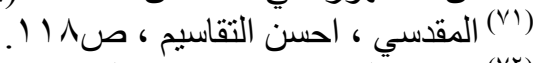

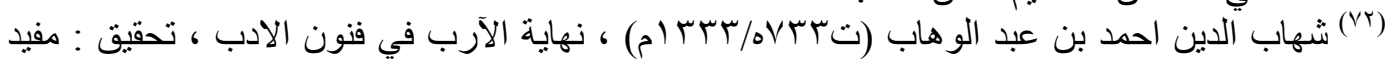

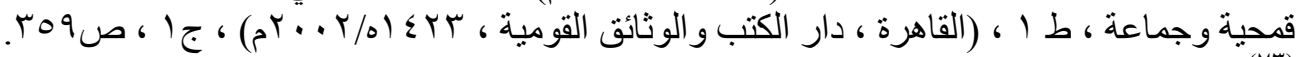

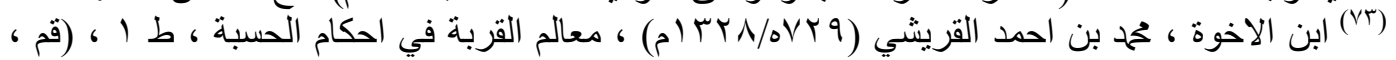

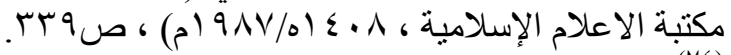

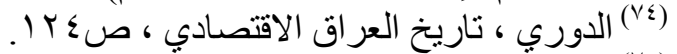

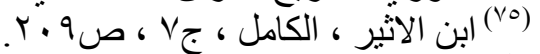

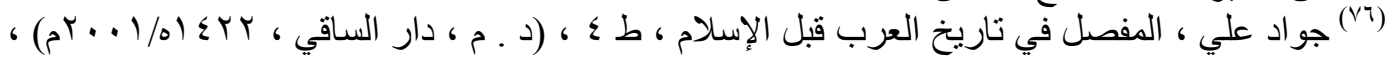

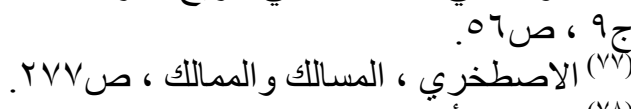
(V)

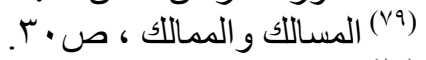

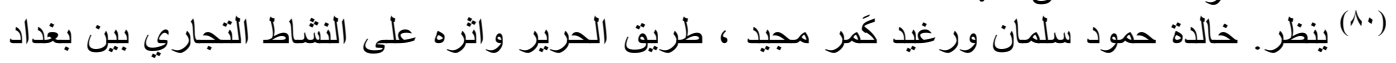

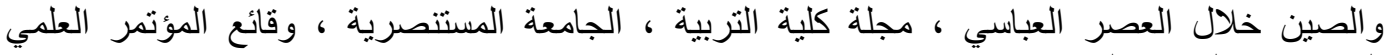

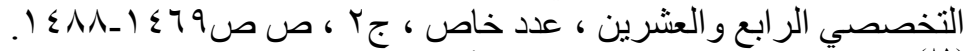

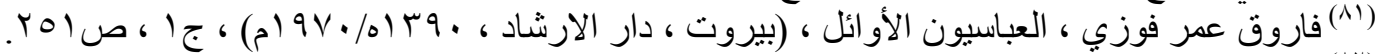

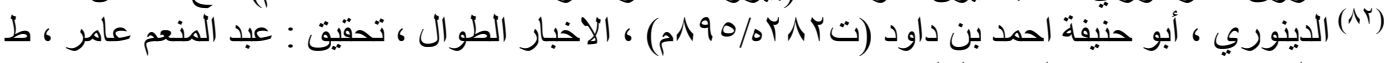

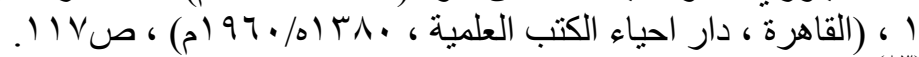

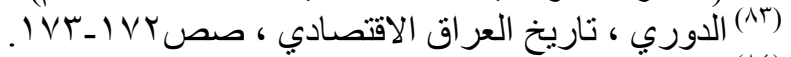

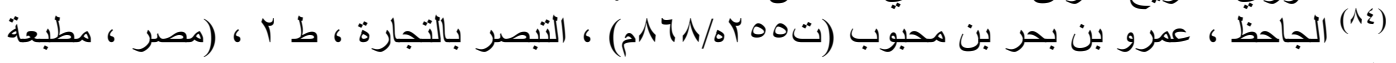

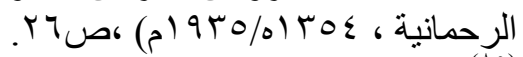
(1)

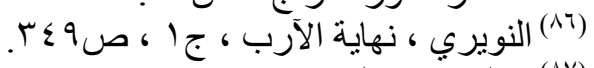

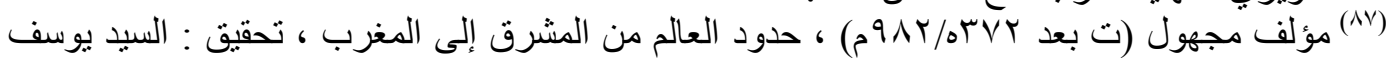

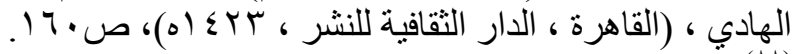
(1^)

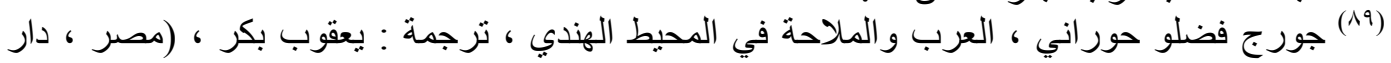

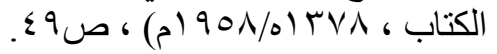


(9.9) الدييل من مدن السند تقع على ساحل البحر الأعظم (المحيط الهندي). ينظر. مؤلف مجهول ، حدود

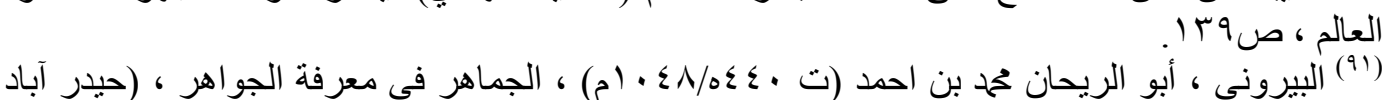

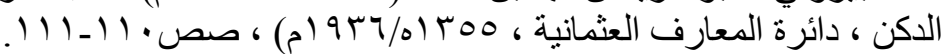

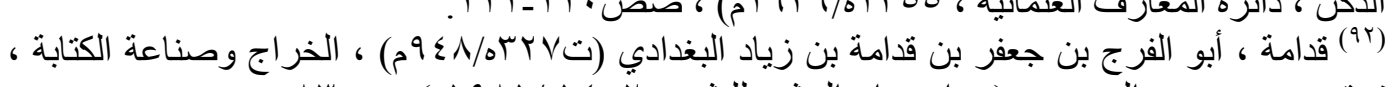

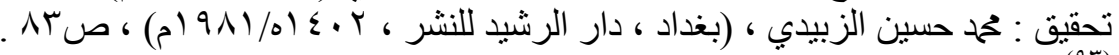

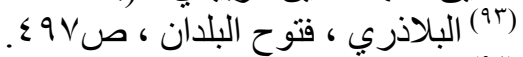

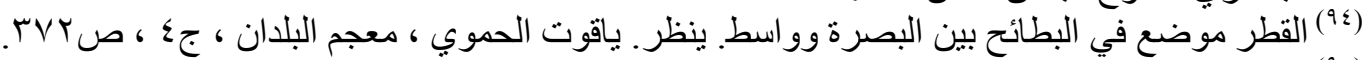

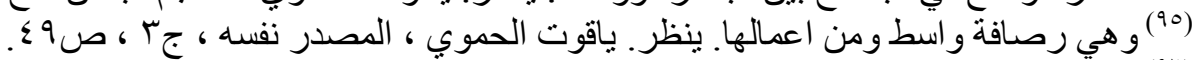

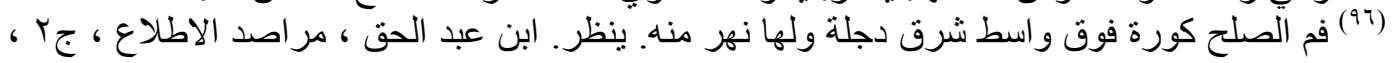

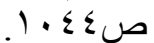

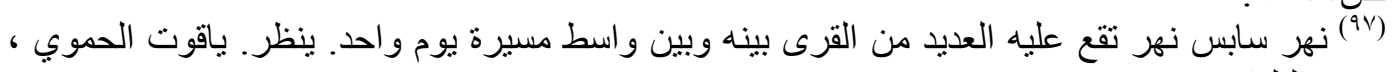

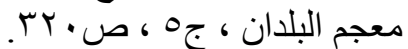

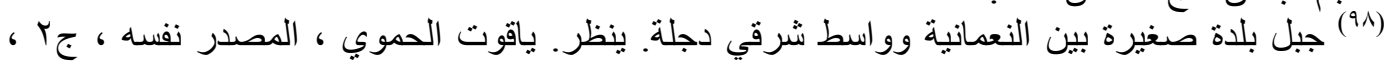

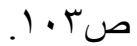
(99) كلو اذي تقع قرب بغداد و هي جانبان ، جانب بغداد و اخر إلى نهر بوق. ينظر. ياقوت الحموي ، المصدر

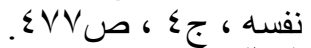

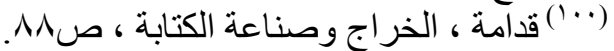

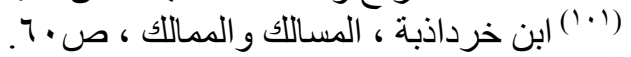

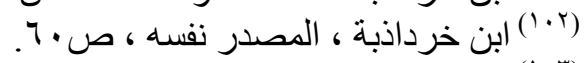

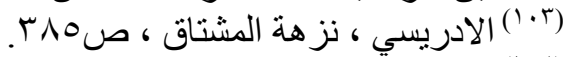

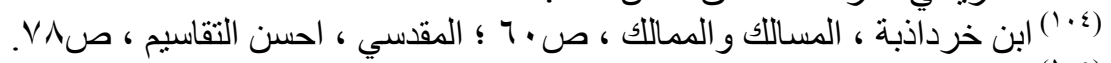

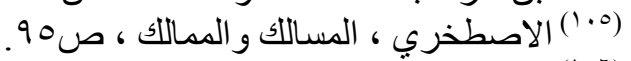

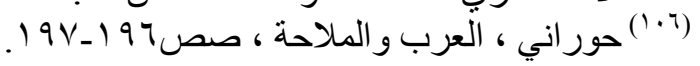

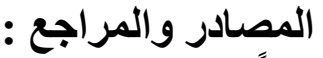
اولاًا : المصادر : المرادع :

• ابن الاثير ، عز الدين أبو الحسن علي بن ابي الكرم محمد بن محمد بن عبد الكريم بن عبد الواحد

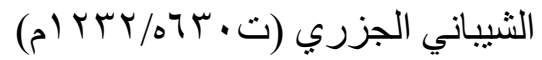

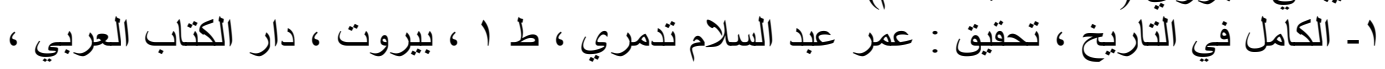
م $99 \mathrm{~V} / 01 \leqslant 1 \mathrm{~V}$

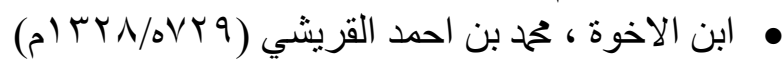

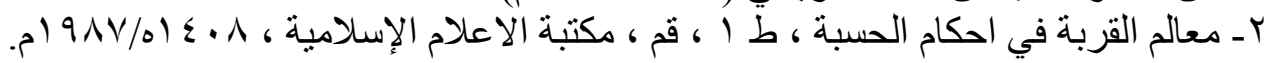

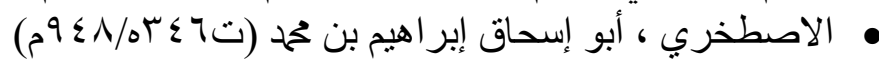

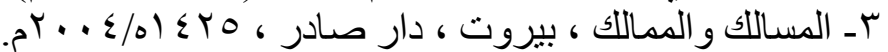

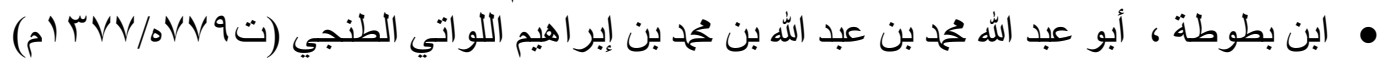
ع- تحفة النظار في غرائب الامصار وعجائب الاسفار ، الرباط ، المائ الكاديمية المملكة المغربية ، $.01 \leqslant 1 \mathrm{~V}$

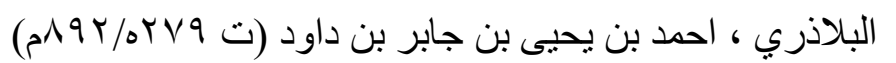

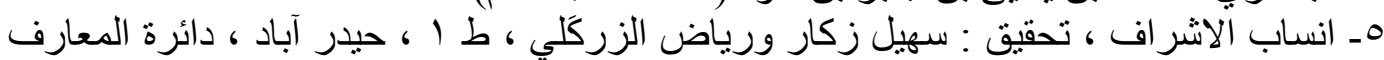

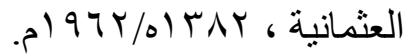

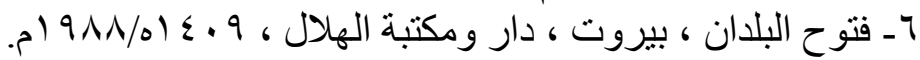

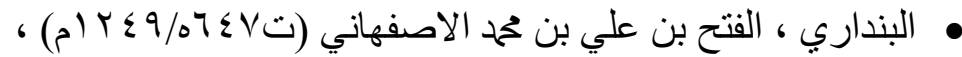

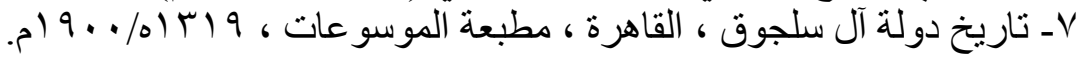

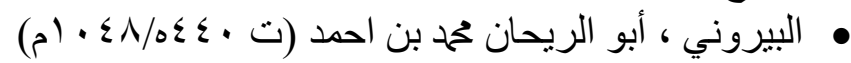

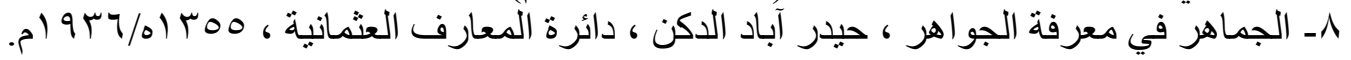

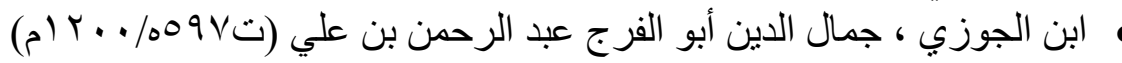




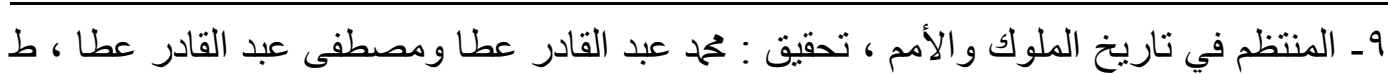

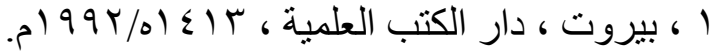

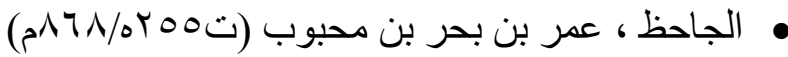

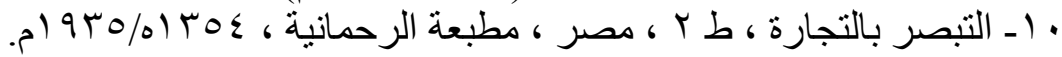

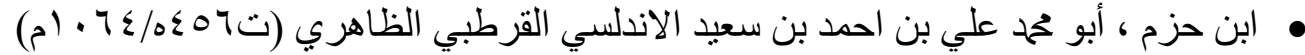

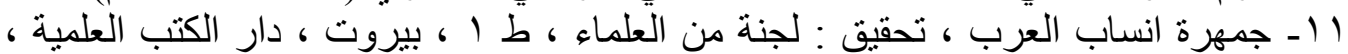

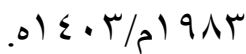

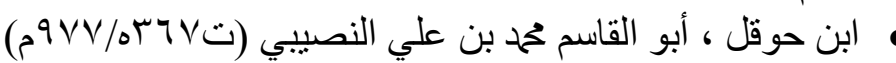

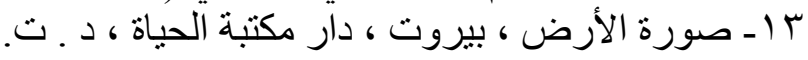

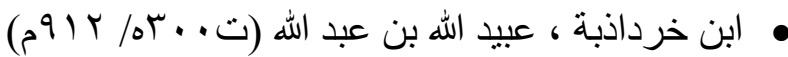

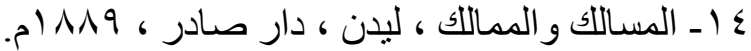

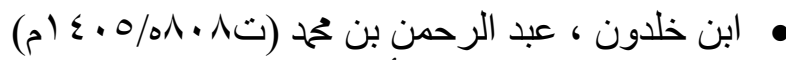

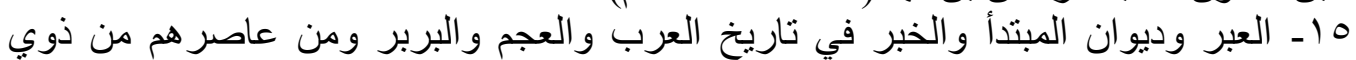

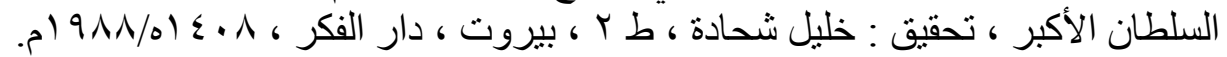

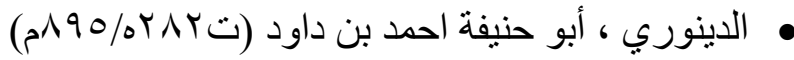

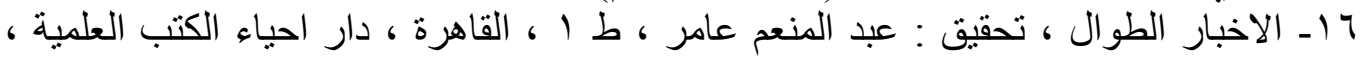
. $197 \cdot / 01 \%$.

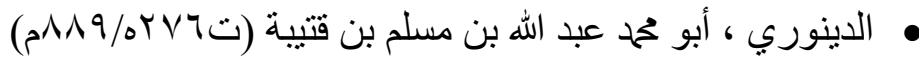

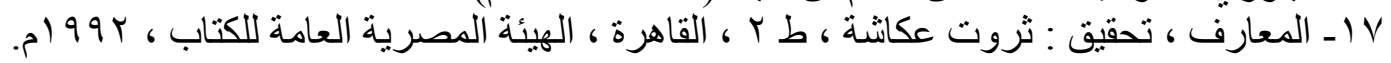

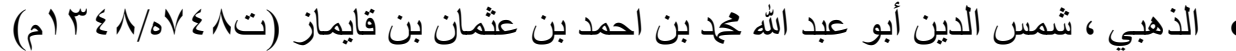

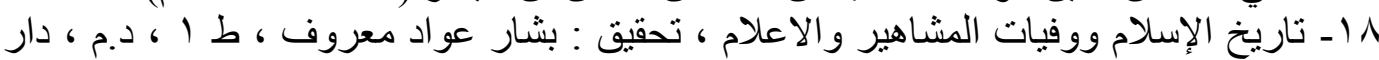

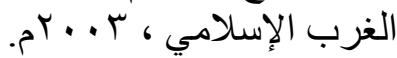
9 ا- سير اعلام النبلاء ، تحقيق : شعيب الارناؤوط ، ط ب ، بيروت ، مؤسسة الرسالة ، . $1910 \% 1 \leq .0$

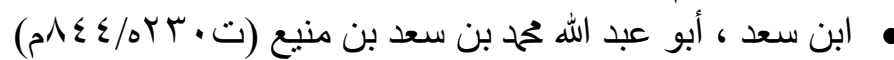

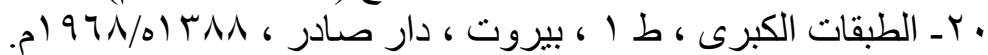

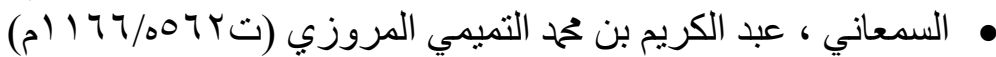

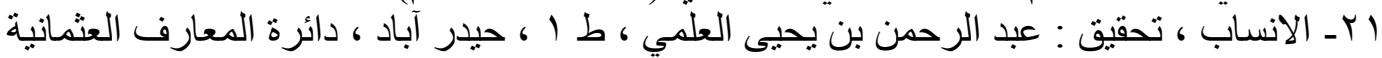

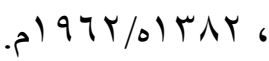
(ت •

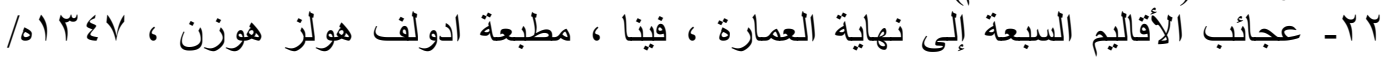
. 949

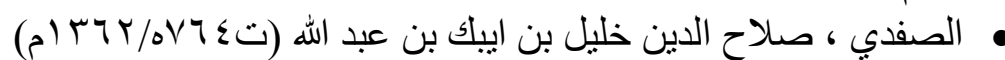

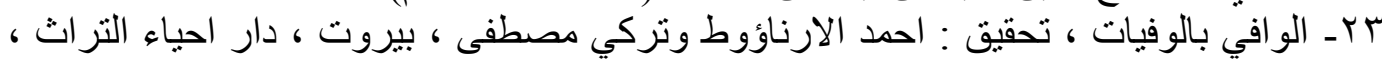
.

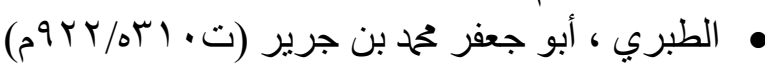

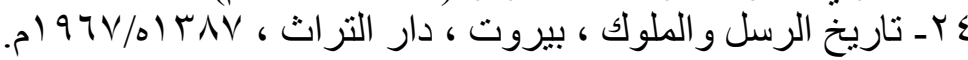

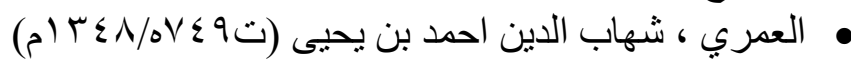

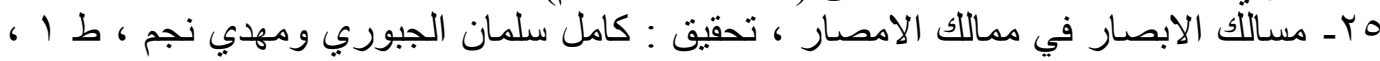

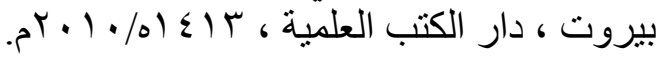

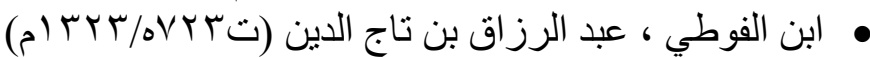

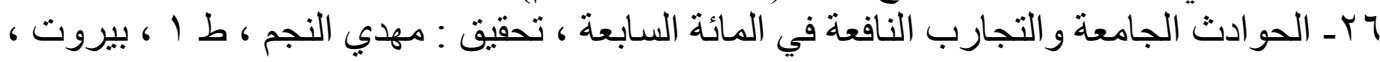

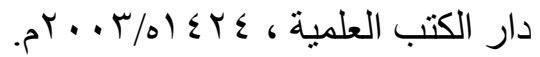

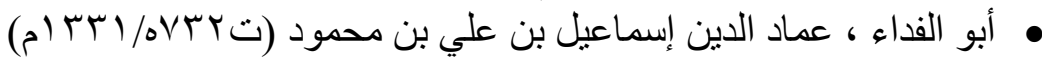

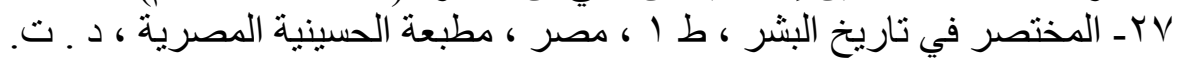




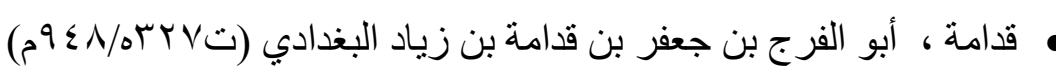

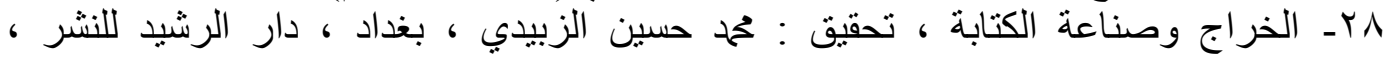
(9)

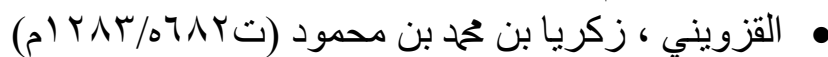

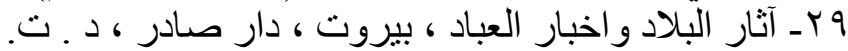

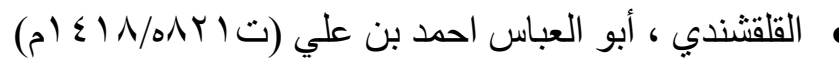

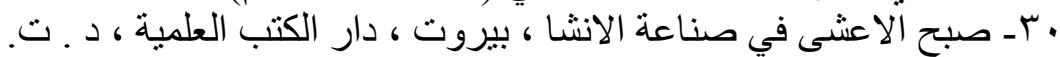

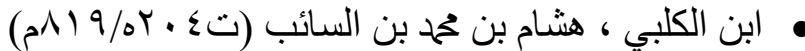

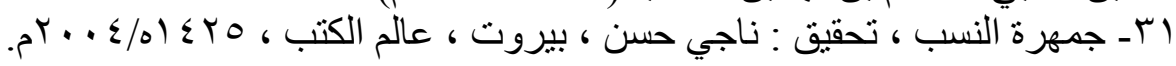

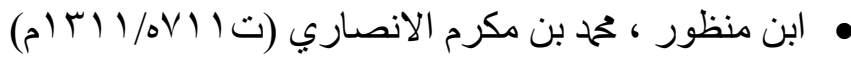

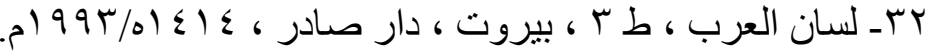

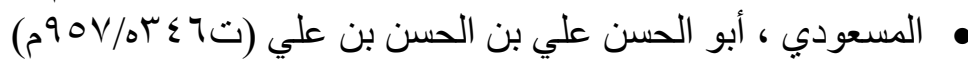

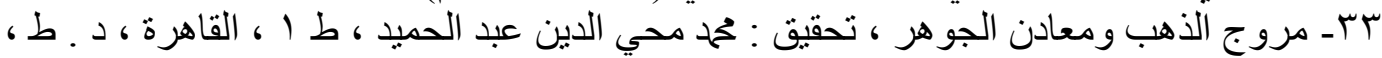
(90N/01TVA

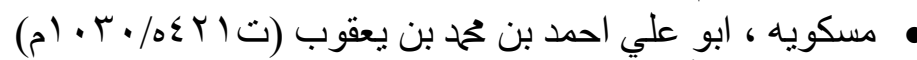

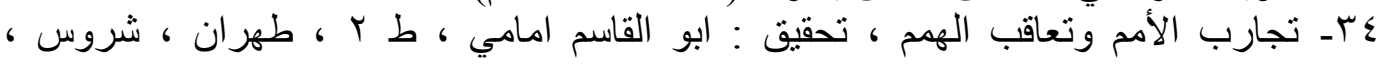
. $r$. . . $101 \leqslant Y 1$

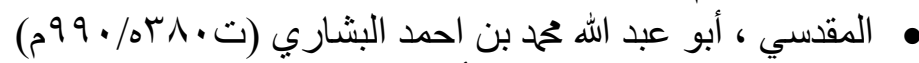

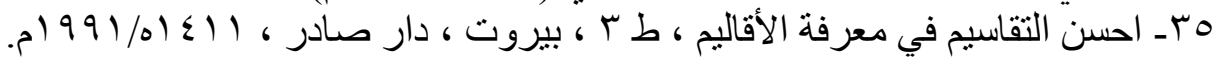

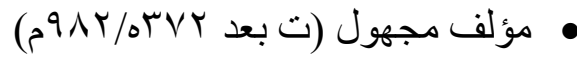
צr- حدود العالم من المشرق إلى المغرب ، ، تحقيق : السيد يوسف الهادي ، القاهرة ، الدار التقافية

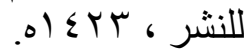
• مؤلف مجهول V Vـ العيون و الحدائق في اخبار الحقائق ، تحقيق : نبيلة عبد المنعم داود ، النجف الاشرف ، مطبعة

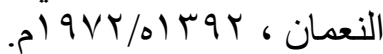

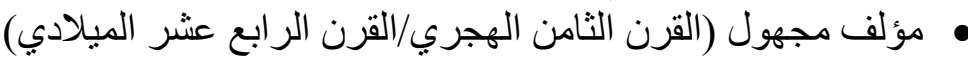

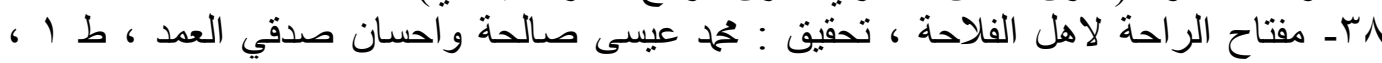

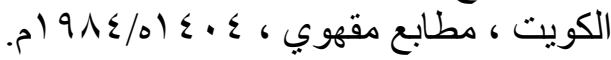

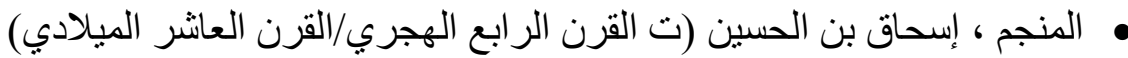

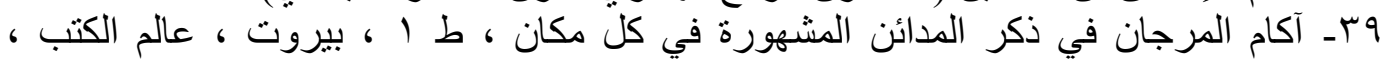
مان $91 \mathrm{~V} / 01 \leq \cdot 1$

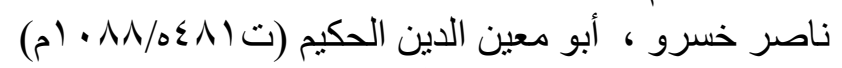

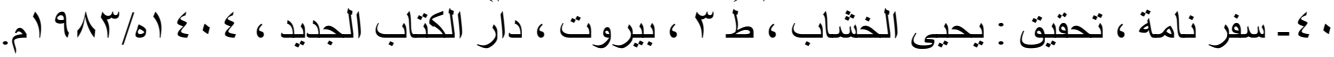

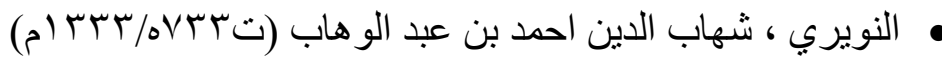

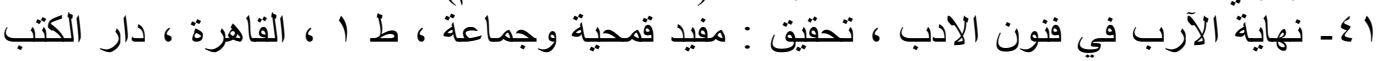

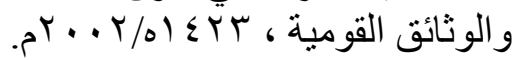

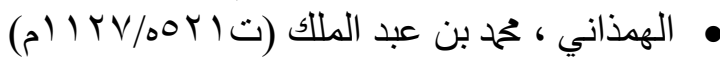

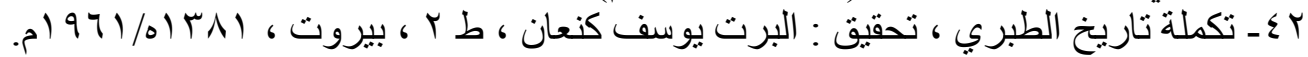

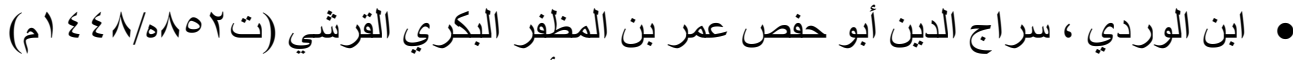

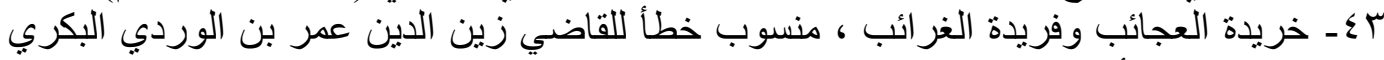

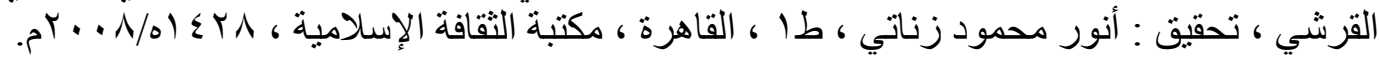

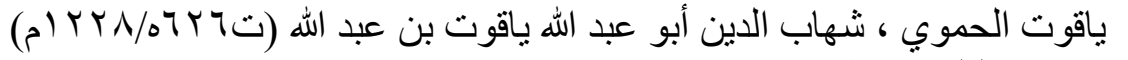

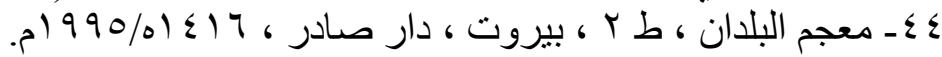




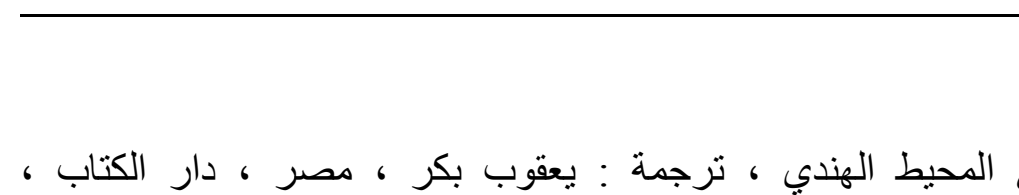

$$
\begin{aligned}
& \text { ثانياً : المراجع : }
\end{aligned}
$$

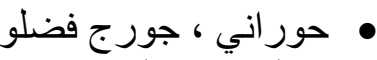

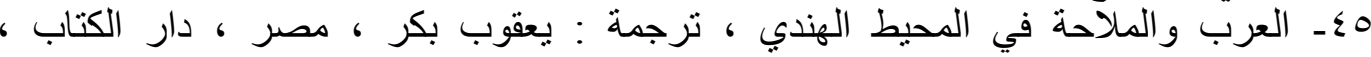

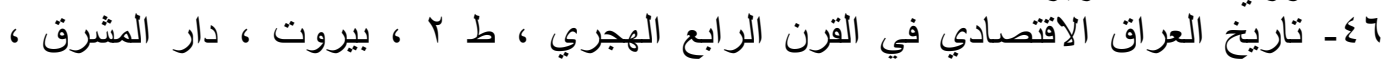

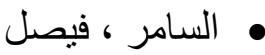

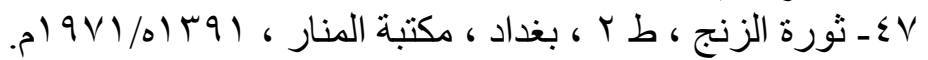

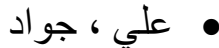

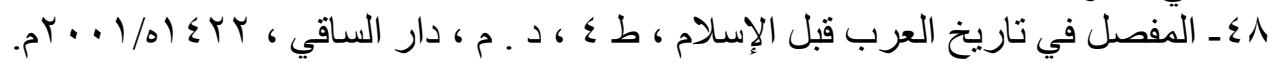

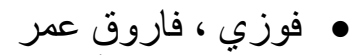

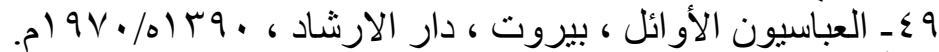

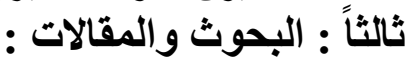

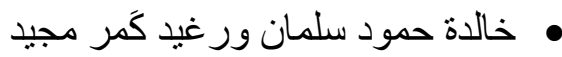

10ـ طريق الحرير و اثره على النشاط التجاري بين بغداد و والصين خلال العصر العبد العباسي ، مجلة

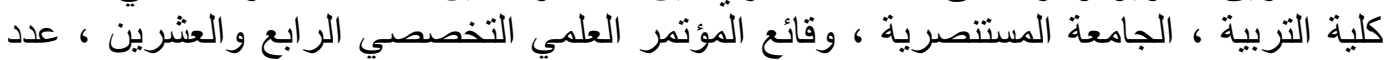

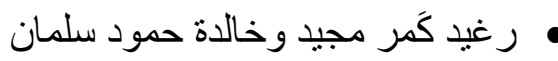

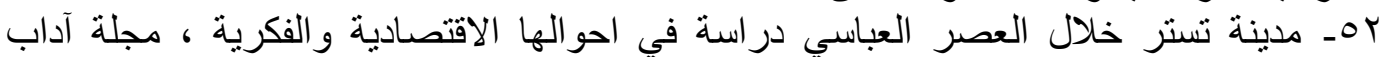

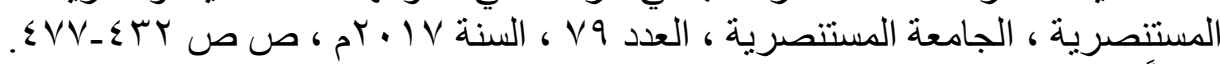

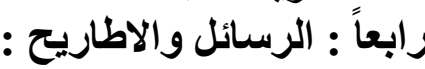

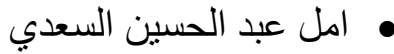

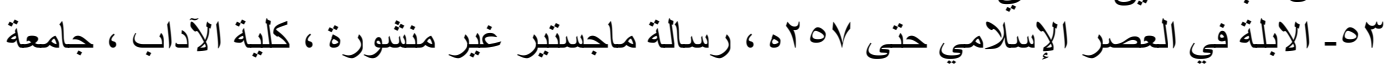

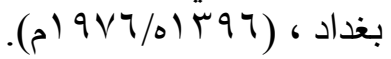

The Political and Economic Conditions to

Abadan City during Abbasid Era

Assistant Professor Dr.Ragheed Gummar Majeed Al Khalidi Assistant Professor Dr.Khaleda Hamood Salman Al Jubouri Al-Mustansiriya University / College of Education / History

Department

Email: ragheed gummar@yahoo.com

\section{Abstract}

The city of Abadan is considered one of the important cities in the Arab Islamic state. It is located on village that is collected the Euphrates and Tigris rivers, rather than represented an important port during Abbasid era. In addition to Abadan city that had witnessed many of political events and wars , the economic activity illustrates the people works in the agricultural, industrial, and traditional fields.

Keywords : Abadan, cities, Political and economic conditions. 